\title{
MAGNETOSTRATIGRAPHY AND KINEMATIC CHARACTERISTICS OF
}

DATCA GRABEN (MUGLA, SW TURKEY)

\section{A THESIS SUBMITTED TO}

THE GRADUATE SCHOOL OF NATURAL AND APPLIED SCIENCES $\mathrm{OF}$ MIDDLE EAST TECHNICAL UNIVERSITY

BY

MERYEM DILAN İNCE

IN PARTIAL FULFILLMENT OF THE REQUIREMENTS

FOR

THE DEGREE OF MASTER OF SCIENCE

IN

GEOLOGICAL ENGINEERING 

Approval of the thesis:

\section{MAGNETOSTRATIGRAPHY AND KINEMATIC CHARACTERISTICS OF DATCA GRABEN (MUGLA, SW TURKEY)}

submitted by MERYEM DILAN INCE in partial fulfillment of the requirements for the degree of Master of Science in Geological Engineering Department, Middle East Technical University by,

Prof. Dr. Halil Kalıpçılar

Dean, Graduate School of Natural and Applied Sciences

Prof. Dr. Erdin Bozkurt

Head of Department, Geological Engineering

Prof. Dr. Nuretdin Kaymakc1

Supervisor, Geological Engineering, METU

\section{Examining Committee Members:}

Assist. Prof. Dr. Erhan Gülyüz

Geological Engineering, Van Yüzüncüyıl University

Prof. Dr. Nuretdin Kaymakc1

Geological Engineering, METU

Assoc. Prof. Dr. Bora Uzel

Geological Engineering, Dokuz Eylül University

Assoc. Prof. Dr. Erman Özsayın

Geological Engineering, Hacettepe University

Assist. Prof. Dr. Ulaş Avşar

Geological Engineering, METU

Date: 10.09 .2019 
I hereby declare that all information in this document has been obtained and presented in accordance with academic rules and ethical conduct. I also declare that, as required by these rules and conduct, I have fully cited and referenced all material and results that are not original to this work.

Name, Surname: Meryem Dilan İnce

Signature: 


\author{
ABSTRACT \\ MAGNETOSTRATIGRAPHY AND KINEMATIC CHARACTERISTICS OF \\ DATCA GRABEN (MUGLA, SW TURKEY) \\ İnce, Meryem Dilan \\ Master of Science, Geological Engineering \\ Supervisor: Prof. Dr. Nuretdin Kaymakc1
}

September 2019, 62 pages

This study involves kinematic development and magnetostratigraphy of infill of the

Datça Graben located at the southwesternmost corner of Anatolia (Turkey). The study comprises kinematic analysis based on fault slip data collected from the margins of the Datça Graben and the magnetostratigraphic analysis of infill of the Datça Graben. For the kinematic analysis, 977 fault-slip data were collected from 44 sites. The data are analyzed using a software which is based on Angelier's reduced stress tensor algorithm. For the magnetostratigraphic analysis, 344 samples are used and the paleomagnetic measurements of those samples are performed in the Fort Hofddjik Paleomagnetism Laboratory, University of Utrecht.

The results of the kinematic analysis have shown that the Datça Basin has developed under the effects of N-S-directed tensional stress regime manifested by WNW-ESEstriking normal faults. As a result of paleomagnetic measurements, the infill sediments of the Datça Graben can be represented by a reversed-normal-reversed polarity pattern, which can be correlated to C2r.1r-C2r.1n-C2r.2r subchrons within the C2r chron of the Early Matuyama in Geomagnetic Polarity Time Scale. This means that the graben filling sediments deposited between 2.3 Ma to 1.9 Ma, in the Late Pliocene. 
This age interval suggests that the Datça Graben has completed its development from half-graben to full-graben geometry by the effects of syn-sedimentary WNW-ESEstriking faults in the Late Pliocene.

Keywords: Datça Graben, Magnetostratigraphy, Paleostress, Southwestern Turkey, Kinematic Analysis 


\title{
DATÇA GRABENI'NIN KINNEMATIK ÖZELLIKLERİ VE MANYETOSTRATIGRAFİSI (MUĞLA, GB TÜRKIYY)
}

\author{
İnce, Meryem Dilan \\ Yüksek Lisans, Jeoloji Mühendisliği \\ Tez Danışmanı: Prof. Dr. Nuretdin Kaymakcı
}

Eylül 2019, 62 sayfa

Bu çalı̧̧ma kapsamında Güneybatı Anadolu'da yer alan Datça Grabeni'nin PliyoKuvaterner yaşlı çökellerinin detaylı yaşlandırılması ve bu çökelmeye tektonizmanın etkileri araştırılmıştır ve ana olarak iki aşamadan oluşmaktadır. Bu aşamalar Datça Grabeni'ni sınırlayan faylar üzerinde kinematik analizler, ve Datça grabeni içerisinde yüzlek veren kırıntılı kayaçların detaylı yaşlandırılması amacıyla gerçekleştirilen manyetostratigrafi çalışmalarını kapsamaktadır. Kinematik analizler için toplamda 44 fay lokasyonundan 977 fay çiziği verisi derlenmiş olup, bu fay çizikleri Angelier stress tensör algoritmasına dayalı bir bilgisayar programı kullanılarak analiz edilmiştir. Manyetostratigrafik kesit çalışmaları için toplamda 102 stratigrafik seviyeden 344 karot örneklendirilmiştir ve bu örneklerin paleyomanyetik ölçümleri Fort Hofddjik Paleyomanyetizma Laboratuarı'nda gerçekleştirilmiştir.

Kinematik analizlerden elde edilen sonuçlara göre Datça Havzası'nı sınırlayan normal faylar yaklaşık K-G doğrultulu bir genişlemeli deformasyon tarafindan kontrol edilmektedir. Hazırlanan manyetostratigrafik kesitten elde edilen polarite değerleri Datça Havzası'nda çökelen birimler için ters-normal-ters olacak şekilde, Erken Matuyama polarite dönemine ait $\mathrm{C} 2 \mathrm{r}$.1r-C2r.1n-C2r.2r alt kronları ile ifade edilebilir. 
Burdan hareketle havza dolgusunun çökeliminin 2.3 My ile 1.9 My (Geç Pliyosen) arasında gerçekleştiği söylenebilir.

Datça Grabeni'ni sınırlayan faylar ve havza içinde gelişmiş olan sedimantasyonla eş yaşlı fayların etkisiyle, Datça Grabeni'nin yarım graben modelinden tam graben modeline evriminin Geç Pliyosen'de tamamlandığı sonucu çıkarılabilir.

Anahtar Kelimeler: Datça Grabeni, Manyetostratigrafi, Paleyomanyetizma, Güneybatı Anadolu, Kinematik Analiz 
To all independent women and their stories... 


\section{ACKNOWLEDGEMENTS}

I would like to thank many people, who contributed to this study. Firstly, I am greatly indebted to my supervisor Prof. Dr. Nuretdin KAYMAKCI for his guidance and encouragement throughout the study.

I am also grateful to Prof. Dr. Cor LANGEREIS for his guidance and assistance during magnetostratigraphic sampling in the field and more importantly his supervision in measuring and interpretation of paleomagnetic samples.

I would like to express my deepest gratitude to Assoc. Prof. Dr. Bora UZEL and Dr. Ökmen SÜMER for fruitfull discussions in understanding the evolution of Datça Graben and its tectonic position in the regional geological context.

I also want to thank the examining committee members, for their valuable comments and their criticism.

This study is carried out as a part of a project supported by The Scientific and Technological Research Council of Turkey (TUBITTAK-117R011). Therefore, I want to thank all the project members Assoc. Prof. Dr. Çağlar ÖZKAYMAK and Prof. Dr. Marious Stoica. In this regard, I would also like to thank Dr. Ökmen SÜMER who gave me the chance to be a part of this project.

I am heartily thanks to Levent TOSUN, Fatih Seçkin ŞIŞ and Mustafa KAPLAN for their assistance during fieldworks and every part of this study. I am grateful for their endless encouragement. Also, I would like to thanks Dr. Murat ÖZKAPTAN for his help during the paleomagnetic sample measurements.

Also, I want to thank my fellow METU research assistants; Akın ÇİL, Gamze TANIK and Serdar Görkem ATASOY for their friendship and support throughout this study. I also would like to thank my dear friends Aslı ŞABAHAT, Deniz YALÇIN, and Zeynep DAYIOĞLU. It would be harder to keep sane during this road without you. Lastly, I want to thank my father Salih INCE and my mother Zeynep İNCE to always be an indestructible wall behind me, and leave me free to fall at the same time. Firuze, my beloved cat, this thesis belongs to you as much as it belongs to me. Thanks for the 
support and the way you show you love me, by sitting on top of my computer and help me to find a word when I am stuck. 


\section{TABLE OF CONTENTS}

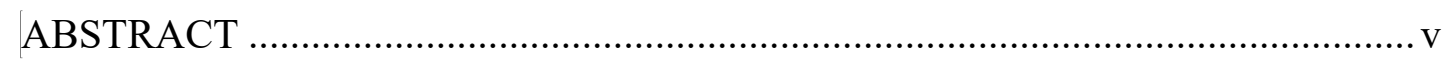

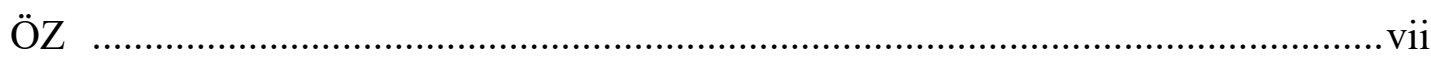

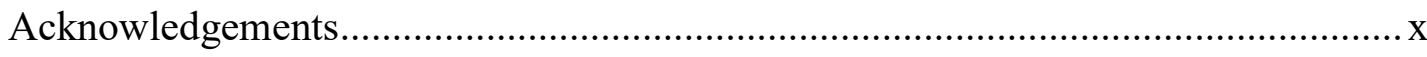

TABLE OF CONTENTS ………………………………..................................

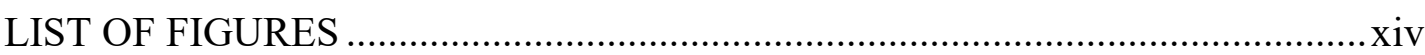

\section{CHAPTERS}

1. INTRODUCTION .............................................................................

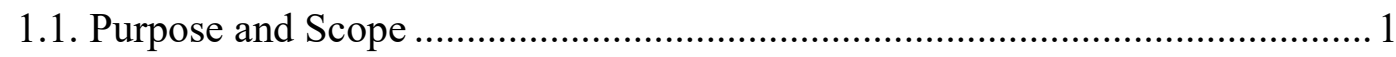

1.2. Geographic Position of the Study Area.......................................................... 2

1.3. Data and Method of the Study ...................................................................

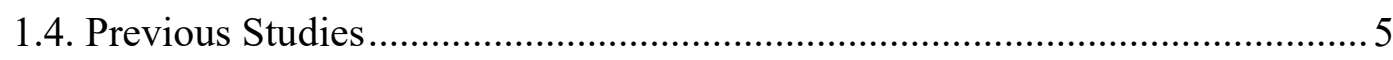

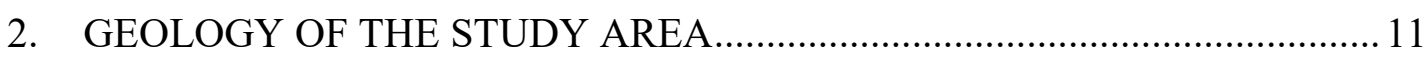

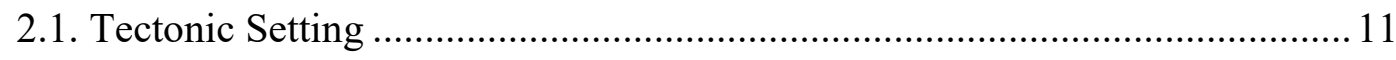

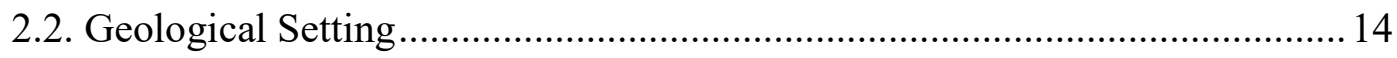

2.2.1. Stratigraphy of the Study Area ................................................................ 16

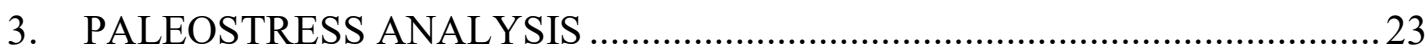

3.1. Paleostress Analysis from Fault Slip Data …………………………………..... 23

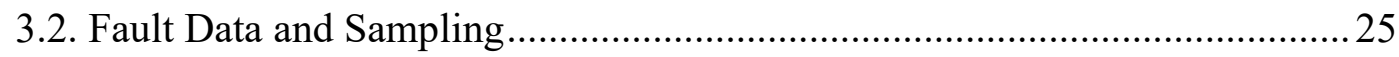

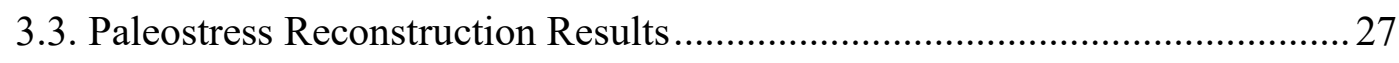

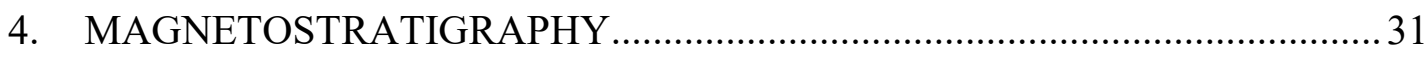

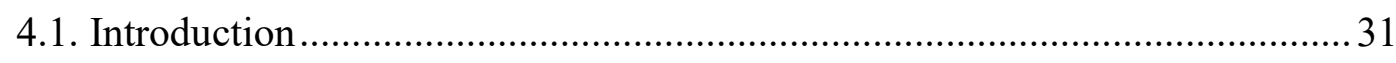

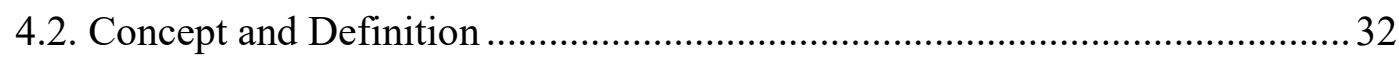


4.2.1. The Paleomagnetic Signal .....................................................................32

4.2.2. The Geomagnetic Polarity Time Scale ....................................................33

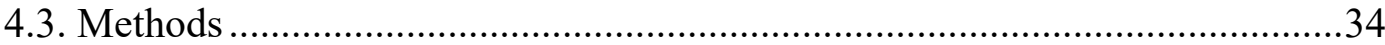

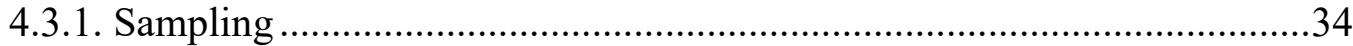

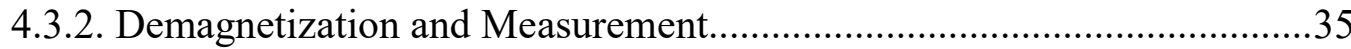

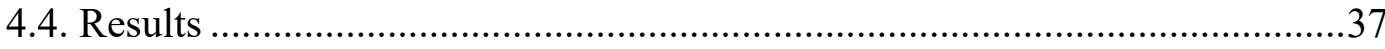

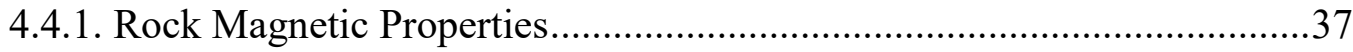

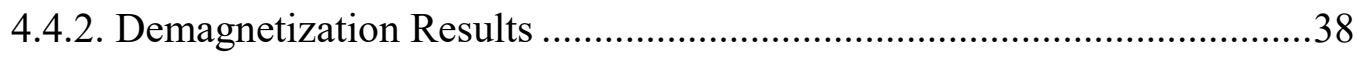

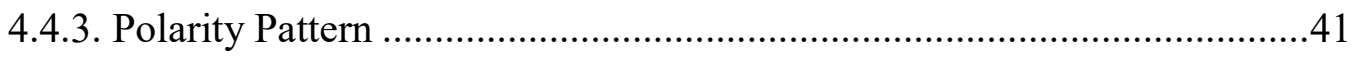

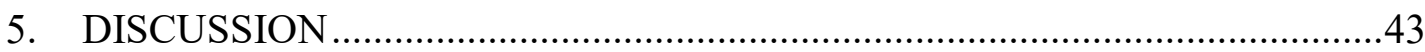

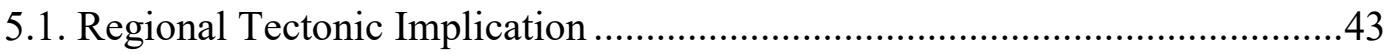

5.2. Correlation to Geomagnetic Polarity Time Scale (GPTS) ..............................44

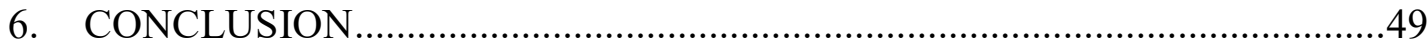

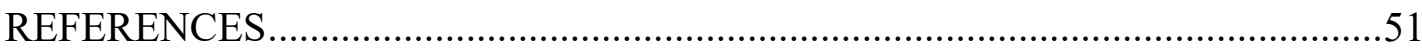

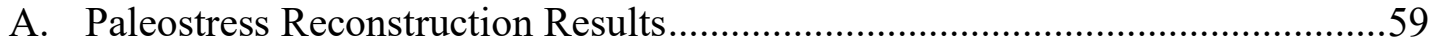




\section{LIST OF FIGURES}

\section{FIGURES}

Figure 1: Simplified tectonic scheme of the Eastern Mediterranean region. (simplified from Le Pichon and Angelier, 1981; Şengör et al., 1985; Bozkurt, 2001; Kaymakci et al., 2018.) 3

Figure 2: (a) Field picture showing sampling procedure using a magnetic compass, (b) Horizontal translation type Curie-Balance measurement device, (c) Magnetically shielded oven used for thermal cleaning procedure, (d) Semi-robotic Alternating Field demagnetization equipment integrated with $2 \mathrm{G}$ Enterprises horizontal DC Squid Magnetometer

Figure 3: General view of the Datça Graben (view from the west)..... 14

Figure 4: Geological map of the study area (prepared by using the data collected during field studies and adopted from Ersoy, 1990 and Dirik, 2007) . 15

Figure 5: Generalized columnar section of the study area (simplified from Ersoy, 1990). 16

Figure 6: (a) Unconformity plane between basement rocks and south-dipping Kızılağaç Formation (NE of Kızlan village), (b) the South dipping Yıldırımlı Formation, (c) Cross-bedding structure observed in Y1ldırımlı Formation, (d) nearly horizontal Karaköy Formation 21

Figure 7: (a) Slickenline lineations on the fault plane located at the northern boundary of the graben, (b) Slickenline lineations on the fault plane located at the southern boundary of the graben, (c) Syn-sedimentary growth faults developed in the infill sediments of the graben, (d) Strike-slip faults developed as transfer faults, (e) Normal fault developed in the infill sediments of the graben. (Arrows indicate the sense of slip on the fault plane) 26

Figure 8: Spatial distribution of the fault sampling sites and paleostress reconstruction results .28 
Figure 9: NW-SE-oriented normal fault and its paleostress reconstruction result.....29 Figure 10: NE-SW-oriented strike-slip fault and its paleostress reconstruction result

Figure 11: Thermomagnetic curves obtained from Curie Balance measurements for DL04, DL12, DM04, and DU49 levels. (red line represents the heating curve, the blue line represents the cooling curve) 38

Figure 12: Results of stepwise thermal (TH) and alternative field (AF) demagnetization results on an orthogonal vector endpoint diagrams (Zijderveld, 1967) performed on samples of different lithologies of Y1ldırımlı Formation. (Red lines to origin represent the best fit of principle component analysis after $\mathrm{TH}$ or $\mathrm{AF}$ demagnetization procedures, open dot symbols indicate inclination while closed dot symbol indicate declination values after each demagnetization steps)..... 40

Figure 13: Paleomagnetic directions showing declination and inclination values for Datca section. (Black circles indicate normal polarity, empty circles indicate reverse polarity, crossed boxes indicate unsampled levels)

Figure 14: N-S oriented 3D block diagram showing the general cross-section of Datça Graben. (elevation data is generated from 1/25000 scale topographic maps of Turkey)

Figure 15: First correlation model to the Geomagnetic Polarity Time Scale (GPTS) (Hilgen et al., 2012) of composite Datça Section. The blue shaded areas have $58 \mathrm{~cm} / \mathrm{Kyr}$, the green shaded area has $82 \mathrm{~cm} / \mathrm{Kyr}$ sedimentation rate. .45

Figure 16: Second correlation model to the Geomagnetic Polarity Time Scale (GPTS) (Hilgen et al., 2012) of composite Datça section. The red shaded area shows the sedimentation rate of $5 \mathrm{~cm} / \mathrm{Kyr}$. .46 



\section{CHAPTER 1}

\section{INTRODUCTION}

\subsection{Purpose and Scope}

SW Anatolia is one of the key regions in understanding the recent tectonic framework of Turkey resulted from two competing tectonic processes since Early Miocene. These are the transcurrent tectonics related to collision and northwards further convergence of Arabian Plate that gave way to the westward escape of the Anatolian Plate, and back-arc extension-related deformation exerted by the slab edge processes in the eastern Mediterranean region (McKenzie, 1978; Meulenkamp et al., 1988; Le Pichon and Angelier, 1978, 1980). The subduction of the African Plate beneath the Anatolian Plate resulted in the formation of Aegean-Cyprian Arc system and a very broad zone of extensional deformation in the Aegean Sea domain and western Anatolia (Le Pichon and Angelier, 1979; Moores et al., 1984; Royden, 1993; Govers and Fichtner, 2016). The Datça Peninsula is located within an area where slab edge processes, such as oceanic subduction, slab detachment, and tearing of subducted slab within the mantle, almost perpendicular to the trench, and associated volcanism interact possible since early Neogene.

These processes resulted in a number of horst-graben complexes some of which nested within older host-graben systems (Koçyiğit et al., 1999). One of the examples to this horst graben structures is located within the Datça Peninsula developed almost in its central part divides the peninsula into there pieces. The Datça Graben is delimited in the north and the south by two well prominent faults. Although the area has been studied for its stratigraphy and structural elements are mapped out, however, the kinematics of these structures and timing and evolutionary history of the Datça Graben formation is still under debated. 
In this context, the main aim of this study is to unravel the evolution of the Datça Graben by employing detailed magnetostratigraphic dating and fault kinematic analysis techniques. Kinematic analysis is based on the fault slip data collected from the graben bounding faults and is aimed at the construction of paleostress configurations that played a role in the development and evolution of the basin. Magnetostratigraphic dating techniques combined with other dating techniques such as biostratigraphy and radiometric dating techniques provide means for the precise dating of the basin in-fill and rate of sedimentation which provides constraints for the age of updateable levels within a sequence. The techniques rely on the determination of normal and reversed magnetic polarities within a rock sequence. Correlation of the obtained polarities with the Geomagnetic Polarity Time Scale(GPTS) provides very precise and high-resolution depositional ages. Obtained ages are crucial for dating the tectonic events that controlled the deposition in the basin.

\subsection{Geographic Position of the Study Area}

The study area comprises the Datça Peninsula located in Muğla Province, SW of Turkey (Figure 1). The area is approximately $170 \mathrm{~km}^{2}$ and lies between $36.42 \mathrm{~N}$ $36.45 \mathrm{~N}$ latitudes and 27.36E-27.48E longitudes and lies within the O19-a3 and O19d2 $1 / 25.000$ scale topographic map quadrangles. 


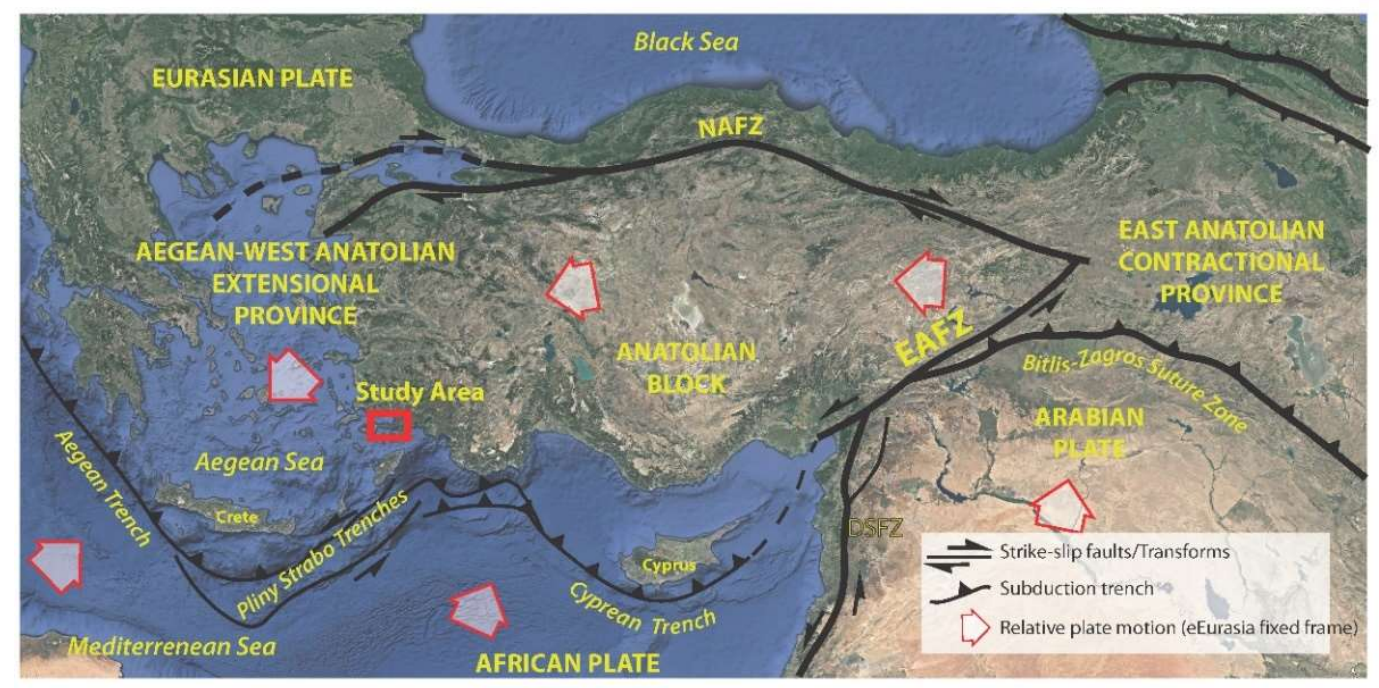

Figure 1: Simplified tectonic scheme of the Eastern Mediterranean region. (simplified from Le Pichon and Angelier, 1981; Şengör et al., 1985; Bozkurt, 2001; Kaymakci et al., 2018.)

\subsection{Data and Method of the Study}

This study was carried out in four main consecutive stages. The first stage involves preliminary studies. During this stage, available literature was collected and investigated. The relevant documents, old reports and prepared maps including topographical and geological maps together within satellite images were collected and thoroughly examined. By using obtained information, the important locations were selected before the fieldwork and simplified geological maps were prepared by using satellite images.

The second stage is the field studies comprising, geological mapping of the study area, sample and data collection for both magnetostratigraphic and paleostress analysis, respectively. During data collection for paleostress analysis, all the graben bounding faults and also the faults formed in the graben filling sediments were visited and data collected from those faults. In total, 977 slickenline data were collected from 44 fault sites. The slickenline lineations and orientations of the fault surfaces were measured 
by using eGEO Compass Pro developed by Marc Foi (2010, last update 2016). For the magnetostratigraphic measurements, three stratigraphic sections were sampled. In total, 344 core samples were collected from 102 stratigraphic levels which are suitable for sampling starting from the lower boundary of graben-filling sediments up to the upper boundary through the dip direction. The core samples were collected by using a gasoline-powered drilling machine, and all samples were oriented by using a compass for the proceeding measurements (Figure 2a).

The third stage was measuring the collected samples. All the demagnetization and measuring processes were held on Fort Hofddjik Paleomagnetism Laboratory in the University of Utrecht. For Curie Balance measurements, horizontal translation-type Curie balance device (Figure 2b) with a noise level of 5.10-9 Am2 was used (Mullender et al., 1993). The demagnetization processes were done by using both thermal and alternative field demagnetization methods. For the magnetic measurements, 2G Enterprises horizontal DC Squid Magnetometer (Figure 2d) with a noise level of 3.10-12 Am2 was used (Mullender et al., 2016). 


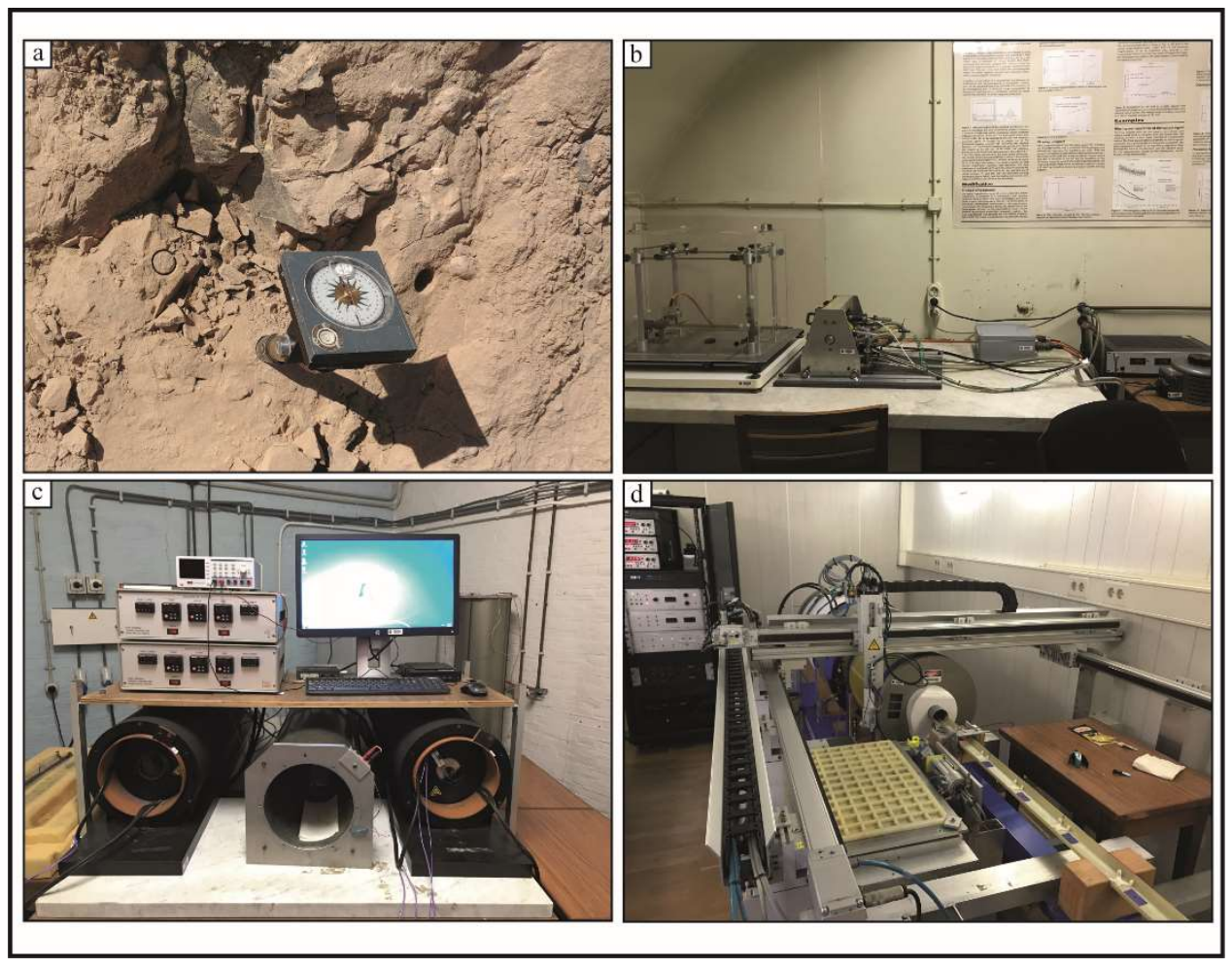

Figure 2: (a) Field picture showing sampling procedure using a magnetic compass, (b) Horizontal translation type Curie-Balance measurement device, (c) Magnetically shielded oven used for thermal cleaning procedure, (d) Semi-robotic Alternating Field demagnetization equipment integrated with 2G Enterprises horizontal DC Squid Magnetometer

The fourth and the final stage mainly comprises office works, which includes integration and interpretation of all gathered results from previous stages. The slickenline data were processed by Win-Tensor (version 5.8.8) software program developed by Delvaux and Sperner (2003). Finally, obtained inclination results from paleomagnetic measurements were gathered and magnetostratigraphic section was prepared for the section. This prepared section was then compared to the Global Polarity Time Scale (GPTS), and the age interval of sedimentation with relative sedimentation rate was calculated for the infill sediments of the Datça Graben.

\subsection{Previous Studies}

Southwestern Turkey has great importance in understanding the neotectonic evolution of the Aegean region and active tectonism occurring in the area. For this reason, southwestern Turkey has been one of the most extensively studied areas with respect 
to its stratigraphy and tectonic evolution, especially its extensional tectonism. Similar to past studies, the subject of this study is to find evidence of extensional tectonism during Plio-Quaternary by analyzing the faults and their relationship with the regional tectonism. Before going into details of the present study, previous studies carried out around the Datça region are discussed in brief.

The previous studies are divided into three categories based on the context of the study. The first group includes studies about regional geology and tectonism which had affected the study area. The detailed information about these studies are given in the regional geology part. The second group is about stratigraphical and paleontological studies carried out in the area. Finally, the last group includes studies about the petrology of the volcanics around Datça and their age determinations. In this context, a summarized review of the key studies is given in chronological order below. First geological observations carried out in Datça Peninsula has been made by Philipson (1915) and Oppenheim (1918). After that, Chaput (1947) documented information about the geomorphology of the region. During the following years, Chaput (1955) included first paleontological observations from the region.

Kaaden and Metz (1954) studied an area between Datça and Dalaman river, and they determined Paleozoic and Mesozoic stratigraphy of the region and explained tectonic structures for both the northern and southern part. Also, the presence of lacustrine sediments in Datça was first recorded by this study.

Tintant (1954) made the first observations on the Pliocene microfauna, and pelecypods and gastropods detected in Datça Peninsula were compared with those in Kos and Rhodes Islands and their similarities were evaluated. In the following year, Chaput (1955) has made similar observations on the Pliocene fauna of Datça Peninsula.

Kaaden (1960) carried out the first petrological study on the ultrabasic rocks. In addition to petrological studies, he included tectonic observations to his study. 
Rossi (1966) and Orombelli et al. (1967) investigated the general geology of the region, and Orombelli et al. (1967) prepared a detailed geological map of Datça Peninsula at a scale of 1:300,000. Moreover, they observed marine transgression for the Pliocene deposits, and claim that they exclusively formed in continental, fluvial, fluvio-lacustrine, transitional lagoonal environment followed by marine transgression.

Becker and Platen (1970) worked on the Neogene macrofossils, and they carried out lithostratigraphic studies in Southwestern Anatolia. Erol (1968, 1976, 1983) summarized the Quaternary shoreline changes on the Anatolian coasts of the Aegean Sea, and they also referred to Datça coasts.

Ercan et al. (1980, 1982a,b) examined the petrology and origin of Quaternary volcanism around Datça peninsula. Considering the petrological characteristics and regional distribution, it was concluded that the origin of Quaternary volcanism is Nysiros volcanics which was active 40,000 to 50,000 years ago and has calc-alkaline characteristics.

Willmann (1980) carried out a study including stratigraphic and paleontological characteristics of Plio-Pleistocene sediments consisting of freshwater gastropods in Greek islands, particularly in Rhodes and Kos. Additionally, he compared the result with the sediments of similar ages deposited in Datça peninsula.

Kayan \& Tuna (1985) discussed the effects of sea-level changes i.e. coastline changes on the urban settlement in Knidos located at the western side of Datça peninsula. In the following years, Kayan (1988) claim that the sea level rose rapidly to the present position by examining the coastal areas along the western coasts of Anatolia.

Ersoy $(1990,1991)$ carried out a study on the geological setting of Datça region during the Neotectonic period, and first illustrated the lateral variation of Pliocene sediments deposited in the Datça Graben. He also proposed two different extension direction occurred during the Neotectonic phase. As a result, he proposed a new model showing that the Datça Graben is situated on top of a greater horst block bounded by Gökova Graben at the North, and Hisarönü Graben at the South. In the following years, Ersoy 
et al. (2000) studied the neotectonic structures belonging to the Lycian Nappes situated between Menderes Massif and Beydağları Autochthon and examined the development of those structures since the late Oligocene. Moreover, he investigated the earthquake activity of the region since 1926 and discussed possible active faults including synsedimentary faults in Datça region that could create earthquakes.

Smith et al. (1996) worked on Kos Plateau Tuff on the island of Kos. According to the age results obtained by Ar-Ar radiometric dating method, he compared them with the eastern Mediterranean stratigraphic successions. In the following years, Allen and Cas (2000) carried out a study in the same area and found out that Datça pyroclastics deposited at the southern part of the peninsula have the same origin and age with Kos pyroclastics.

Kapan Yeşilyurt \& Taner (2002) made observations on the pelecypods and gastropods fauna of Neogene units outcropping around Datça peninsula. Observed fossils indicate that the age of Y1ldirımlı formation is determined as of late Piacenzian. Electron Spin Resonance (ESR) dating method is applied to four fossil shells, and obtained results supported the late Piacenzian age. In addition to paleontologic studies, they proved the existence of lagoonal depositional environment by checking freshwater facies once again.

Altunel et al. (2003) carried out a study about Knidos Fault which is located at the southwest of Datça peninsula, tried to find out the deformational history of the region by investigating the deformations on the archeological remains. According to the observed data, they claimed that the region has affected at least two main seismic activity created by active Knidos Fault.

Dirik et al. (2003) mapped a number of NE-SW, NW-SE and E-W-trending faults including faults that form the graben boundaries at a scale of 1:25,000, and they included stratigraphy studies for both basement and cover units. Structural elements of paleotectonic and neotectonic phases are investigated and their relationship is investigated with the earthquake history of the region. Furthermore, the effects of 
geomorphological properties of the region on the settlement of ancient civilizations are discussed. In the following years, Dirik (2007) repeated his investigations on the graben bounding faults, and remapped the E-W, NE-SW, NW-SE faults and correlated their effects on the Datça Graben development.

Çiftçi (2010) carried out a master degree about the geology on Datça and stated the detailed stratigraphy and structural elements of the region.

Kuşçu and Uslular $(2017,2018)$ presented new distal records of tephra deposits in seven locations of Datça peninsula. They compared those tephra samples of Datça region with Kyra and Nisyros tephra units. As a result, Datça tephra deposits are associated with proximal Kyra subunits of intermediate composition and Nisyros volcanics. 



\section{CHAPTER 2}

\section{GEOLOGY OF THE STUDY AREA}

\subsection{Tectonic Setting}

Turkey is one of the seismically active regions of the world, and it is located on the Mediterranean Earthquake Belt. The continental collision of the African and Eurasian plates since the Early Mesozoic times contributes to the active tectonics of Turkey, as it is expressed by collisional intracontinental convergence in eastern Turkey and tectonic escape-related extensional deformation in western Turkey. Presently, Turkey can be outlined by three major structures as the Aegean-Cyprian subduction, on which Arabian plate has been moving towards north near South Aegean-Cyprian subduction zone at a rate of $8 \mathrm{~mm} /$ year (McClusky et al., 2000), and two intracontinental transform fault zone named as dextral North Anatolian Fault Zone (NAFZ) and sinistral East Anatolian Fault Zone (EAFZ) (Figure 1). In addition, Dead Sea Fault Zone (DSFZ) in the southeastern part of Turkey plays an important role in the active tectonics of Anatolia. The Aegean-Cyprian Arc is migrating through the southwest, and this southwestward migration is a consequence of the roll-back of the Neotethyan slab beneath the Anatolia (Le Pichon and Angelier, 1979; Moores et al., 1984; Royden, 1993; Govers and Fichtner, 2016). The dextral NAFZ and the sinistral EAFZ meet at Karlıova region located in northeastern Turkey and form a continental triple junction. The Anatolian wedge is moving along these strike-slip systems through WSW direction onto the eastern Mediterranean lithosphere under the effect of the convergence between Eurasian and Arabian plates. This movement causes a counterclockwise rotation accompanied by a westward escape of the Anatolian plate with the movement rate of $35 \mathrm{~mm} /$ year (McClusky et al., 2000). As a result of these intracontinental deformations, Anatolia is also subjected to an internal deformation, hence four different neotectonic provinces have been generated. These are the East Anatolian contractional, the North Anatolian Province, the Central Anatolian 'Ova' 
and the West Anatolian extensional provinces (Şengör et al., 1985; Bozkurt, 2001, Koçyiğit, 2009; Figure 1).

Western Turkey is a perfect laboratory to study continental extension as the region has been experiencing approximately N-S-directed extension since at least the Latest Oligocene-Early Miocene times (Şengör et al., 1985). The extension is influenced under the effect of forces caused by northward subduction of the African plate along Aegean-Cyprian subduction zone and North Anatolian fault system. The northward motion of Arabian plate relative to Eurasia also affects the deformation in western Turkey since it leads to crustal thickening, shortening and regional uplift in eastern Turkey. As a result of N-S-directed extension, approximately E-W-trending grabens are the most prominent features in western Turkey.

Although the presence of extensional tectonism is accepted, the origin and the age of the crustal extension in western Turkey is still the subject of major controversies. There are five different models proposed to solve this paradox:

(i) Back-arc spreading model - This model argues that the main cause of the extension is the southwestward roll-back and resultant migration of Aegean-Cyprian subduction zone along which the African plate is subducting beneath the Anatolian plate, and create an extension in the upper plate caused by back-arc spreading. The timing of subduction roll-back process is still debated, but it is claimed that the proposed ages range between $60 \mathrm{Ma}-5 \mathrm{Ma}$ (McKenzie, 1978; Meulenkamp et al., 1988; Le Pichon and Angelier, 1978, 1980).

(ii) Tectonic escape model - This model argues that the extension started in the Late Serravalian ( $\sim 12 \mathrm{Ma})$ and is a result of westward escaping of Anatolian wedge between the bounding transfer strike-slip fault systems, dextral NAFZ and sinistral EAFZ (Şengör, 1979; Şengör et al., 1985; Şengör, 1987; Dewey and Şengör, 1979). However, recent studies confirmed that the age of transfer fault systems is Pliocene (Barka et al., 1988) which is much younger than previously thought. Because of this, 
the tectonic escape model cannot completely explain the whole history of the extension in western Turkey.

(iii) Orogenic collapse model - This model argues that after cessation of the Latest Paleogene collision between Sakarya continent in the north and Anatolide-Tauride platform in the south across Neotethyan Ocean along İzmir-Ankara suture, the overthickened crust has been thinning and spreading, and orogenic collapse has occurred (Seyitoğlu and Scott, 1991, 1992). The age of orogenic collapse was attributed to Latest Oligocene-Early Miocene by using the geochronological data from synextensional granites and mylonitic fabrics of Menderes Massif (Hetzel et al., 1995; Gessner et al., 2001; Işı1k and Tekeli, 2001; Lips et al., 2001; Iş1k et al., 2004).

(iv) Episodic -two-stage graben model - According to this model, the extension has occurred in two distinct structural styles of different timing. First extension stage has occurred in Early-Middle Miocene as core complex formation, and then it was followed by the latest stage of extension, which occurs as Plio-Quaternary normal faulting and graben formation. According to Koçyiğit et al., 1999, these two extensional stages are separated by an interval of N-S crustal shortening during Late Serravalian- Early Pliocene times. The origin of the extensional stages was attributed to the orogenic collapse model and westward escape of the Anatolian block (Koçyiğit et al., 1999).

(v) More recent studies claim that the extension in western Turkey and in the Aegean region is a result of differential convergence rates between northeastwarddirected subduction of the African plate relative to the Anatolian plate. They also claim that the main reason for the extension is the relatively rapid southwestward movement of Greece relative to Anatolia (Doglioni et al., 2002). 


\subsection{Geological Setting}

Datça Peninsula is located on the southwestern tip of the Anatolian coast and is surrounded by Gökova Bay in the North, and Datça Bay in the South. The peninsula is approximately E-W-trending, $65 \mathrm{~km}$ long and a few $\mathrm{km}$ wide. In the central part of the peninsula, an interesting depression seems a characteristic feature. This depression is first named as Datça Isthmus by Chaput (1947), but after revealing both northern and southern boundaries of the depression are faulted, it has been named as Datça Graben by Ersoy (1990). Although it is a depression, in the central part of Datça graben, the hills and ridges are located and that topographically high area is underlain by the late Pliocene deposits dipping through the south with a dip angle of about 20 degrees. The northern part of the graben is topographically lower when compared to the southern part, and the slopes are decreasing through the southern margin of the graben (Figure $3 \&$ Figure 4). The southern margin of the graben is topographically higher and bounded by a mountain front, the hills are reaching up to $1100 \mathrm{~m}$ elevations. At the northern margin, the basement rocks juxtapose with Kızılağaç Formation and Y1ldırımlı Formation, while at the southern margin the basement rocks juxtapose with Yildırımlı Formation and Karaköy Formation. In the stratigraphy section, the detailed information about those formations and the contact relationships will be given.

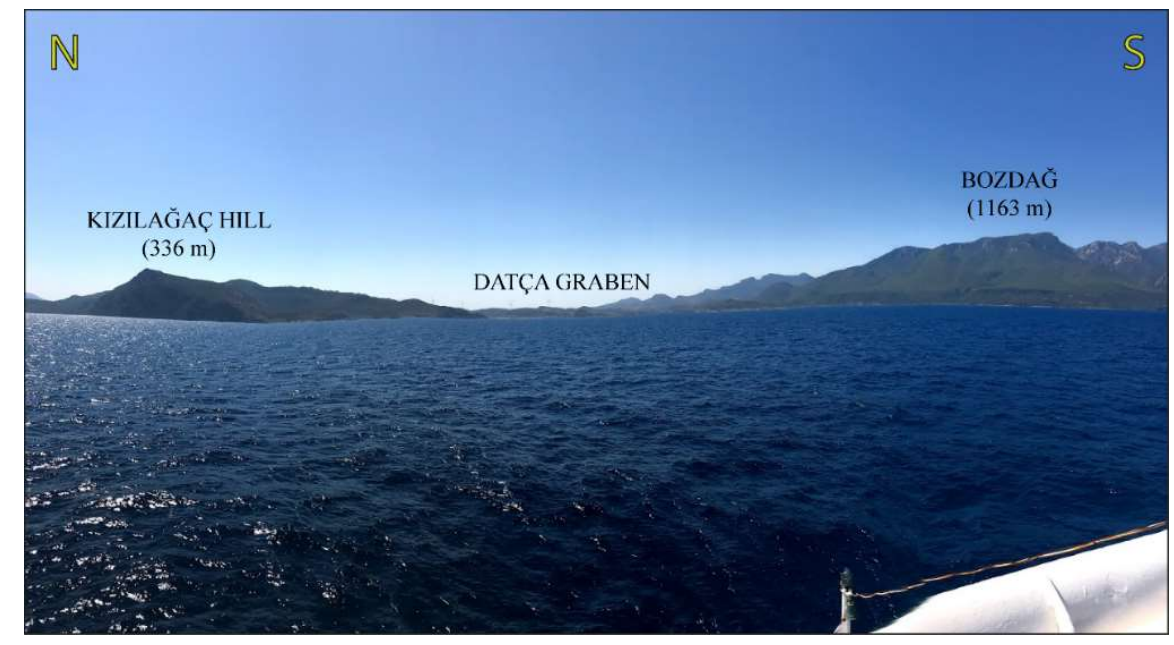

Figure 3: General view of the Datça Graben (view from the west) 


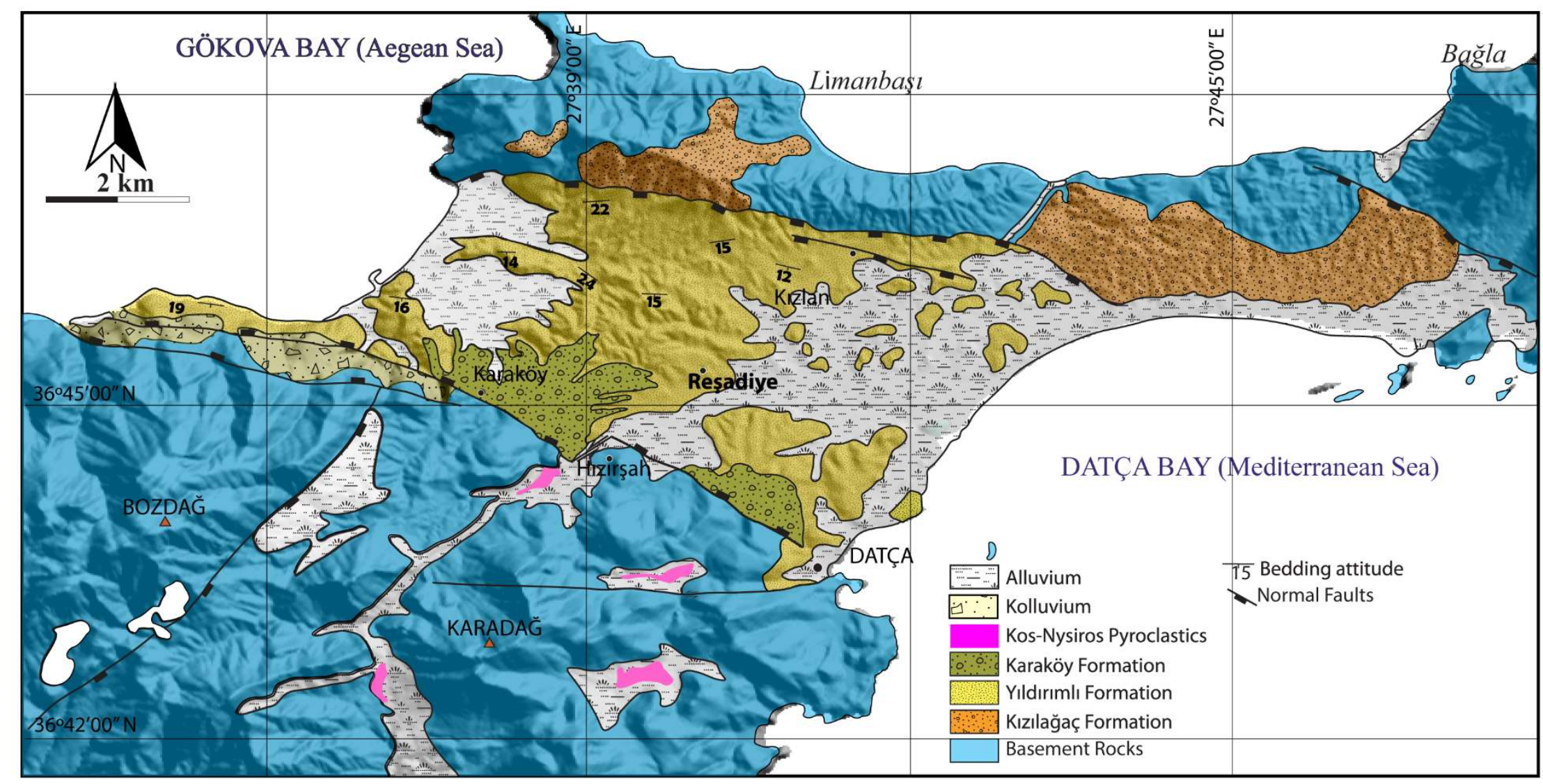

Figure 4: Geological map of the study area (prepared by using the data collected during field studies and adopted from Ersoy, 1990 and Dirik, 2007) 


\subsubsection{Stratigraphy of the Study Area}

The units, which are exposed in the Datça Peninsula, are divided into two as basement rocks and cover sequences. Basement rocks broadly include the pre-Neogene rock units, whereas the cover sequence includes the Neogene and post-Neogene sedimentary sequences. (Figure 5)

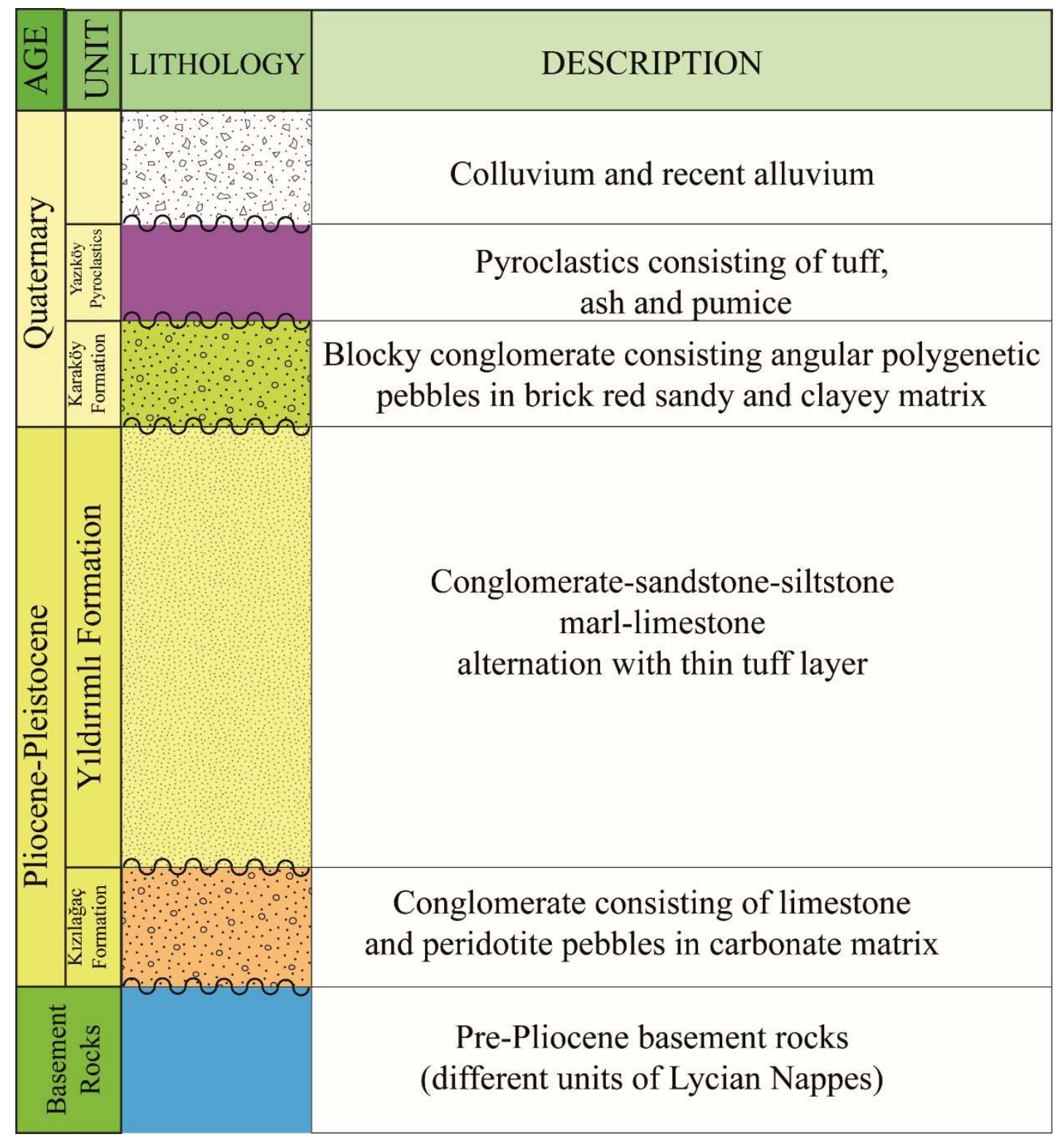

Figure 5: Generalized columnar section of the study area (simplified from Ersoy, 1990) 


\section{Basement rocks}

The basement rocks consist of different units of Lycian Nappes and are divided into three in accordance with the tectonostratigraphy of the region as lower, middle and upper tectonic slices. The main lithologies of the tectonic slices will be given without mentioning the formation names below. The lower tectonic slice includes ophiolite and Upper Cretaceous ophiolitic mélange, while the blocky flysch of Late Cretaceousearly Eocene forms the middle tectonic slice. Upper tectonic slice starts with Upper Triassic-Lower Jurassic massive platform carbonates, and at stratigraphically higher levels, there are radiolarite, chert and cherty limestone levels of Late Cretaceous- Late Jurassic time. The uppermost part of the basement rocks consist of blocky flysch levels of Late Cretaceous-early Eocene, and it is unconformably overlain by Pliocene sedimentary sequences (Ersoy, 1990; 1991).

\section{Cover Sequences}

There is an important time gap between pre-Neogene basement rocks and the PlioQuaternary cover sequence in the Datça Peninsula. The Early Pliocene Kızılağaç Formation, the Latest Pliocene Y1ldırımlı Formation unconformably overlies the older rocks in the region. The Yildırıml Formation unconformably overlies the Karaköy Formation in marginal facies character. Other than that formations, the youngest lithologies outcropping in the region is Yazıköy pyroclastics, terrace deposits, colluviums, talus, alluvial fans, beach rock, beach sand and gravel, and alluvium consisting of the younger cover units.

\section{Kızılă̆aç Formation}

This unit is observable on the northern side of the Datça graben, and it is first named by Dirik (2007). It is well exposed on the northeast and northwest part of the Kizlan village (Figure 6a). The sequence unconformably overlies the ophiolitic mélange and massive carbonates of Lycian Nappes at the north and starts with conglomerate consisting of peridotite and limestone pebbles in a carbonate matrix. Locally, near around Kızılağaç Hill located on the northwestern side of the graben, it consists 
limestone pebbles. Before it is discriminated as a different formation, it was involved in the continental clastics of Y1ldırıml1 Formation. Based on its stratigraphic position, Ersoy (1990) have attributed the Early Pliocene age for this formation.

\section{Ylldırımlı Formation}

This unit is first named by Rossi (1966) as Y1ldırımlı Formation and Pliocene age is attributed to the unit by this author. Later, Görür et al. (1995) named the same formation as Datça Formation, but because of the priority, Yıldırımlı Formation will be used in this study.

Lower parts of Y1ldirıml Formation displays great lithological changes along the northern margin of the graben. This situation can be observed from where the base of the formation is outcropping through the northern bounding fault of Datça Graben. At the west of the Kızlan village, around Kızılağaç Hill, there are conglomerate levels that consist of ophiolite and chert pebbles in a carbonate matrix. More eastwards, the lithology is changed into lacustrine thick-bedded, white-colored oolitic limestone consisting of ophiolite and chert fragments. At the most eastern side, the lithology is oolitic, pisolitic and concretional limestone (Ersoy, 1990).

The Yıldırımlı Formation is outcropping widespread around Reşadiye, Hızırşah, Kızlan and Körmen vicinities (Figure 6b,c). At the western part of Körmen, the unit is characterized by conglomerate, sandstone and marl alternation. The pebbles of conglomerate consist of serpentinite, gabbro, and radiolarites. The sandstone beds are interlayered with yellow-beige and gray marl and claystone layers which consist of abundant fossils. This unit also contains a gray-colored tuff layer at around Y1ldirım Hill. Upward this sequence, the unit grades into the lacustrine sediments consisting of conglomerate, sandstone, claystone, marl, and rare limestones and dolomites. The synsedimentary fluvio-lacustrine depositional environment can also be observed in Datça Graben. This is very common in the Aegean region and Mutti et al. (1970) mention that the Lower Levantian fluvio-lacustrine sediments in Rhodos show similar characteristics with Y1ldırımlı Formation. Kaaden and Metz (1954) first revealed the 
presence of lacustrine depositional environment in Datça Graben on the basis of the macrofossils collected from the northwest of Hızırşah village. Kapan-Yeşilyurt and Taner (2002) attributed the late Piacenzian age to the Y1ldırımlı Formation based on the gastropods-pelecypods fauna. Also, according to the Electron Spin Resonance (ESR) dating, the age of the unit is given as 1.891-1.998 Ma (Kapan-Yeşilyurt and Taner, 2002).

In the Datça Graben, both the lateral and vertical lithologic variations and fossil descriptions indicate fluvio-lacustrine deposition followed by rapid marine transgression and finally sudden regression.

\section{Karaköy Formation}

At the northwest of Datça along the southern margin of Datça Graben and around Karaköy, Karaköy Formation is well exposed. The unit is firstly discriminated from other Quaternary sediments in Dirik (2007) and first named as Karaköy Formation.

Karaköy Formation is characterized by red color (Figure 6d). Nearly horizontal Karaköy Formation unconformably overlies the Y1ldırımlı Formation. It is characterized by angular conglomerates with polygenetic pebbles settled in brick-red colored sandy and clayey matrix. It is developed as a marginal facies of Datça Graben due to rapid uplift and erosion took place at the western part of the Reşadiye horst. The grain size decreases away from the margin and the lithology grades into red sandstone, greenish-yellow claystone-mudstone alternation.

The age must be early Quaternary because it unconformably overlies the late Piacenzian Yıldırımlı Formation (Dirik, 2007). 


\section{Yazıköy Pyroclastics}

The Yazıköy pyroclastics are well exposed in the valleys and coastal sections of Datça peninsula. It is first named by Dirik (2007), and the source of the pyroclastics is attributed to the end of the modern Aegean volcanic arc which is extending from the Greek mainland to Turkey (Dewey and Şengör, 1979; Ercan et al., 1984; Allen and Cas, 2002). In Allen and Cas (2002) this formation is named as Kos Plateau Tuff (KPT) and according to these authors, the source of KPT was between Kos and Nysiros Islands and flows crossed open sea to the South and East of the source in the eastern Aegean Sea. According to the single-crystal Ar-Ar analysis of sanidine crystals, the Yazıköy pyroclastics were dated as 161 ka by Smith et al. (1996). 

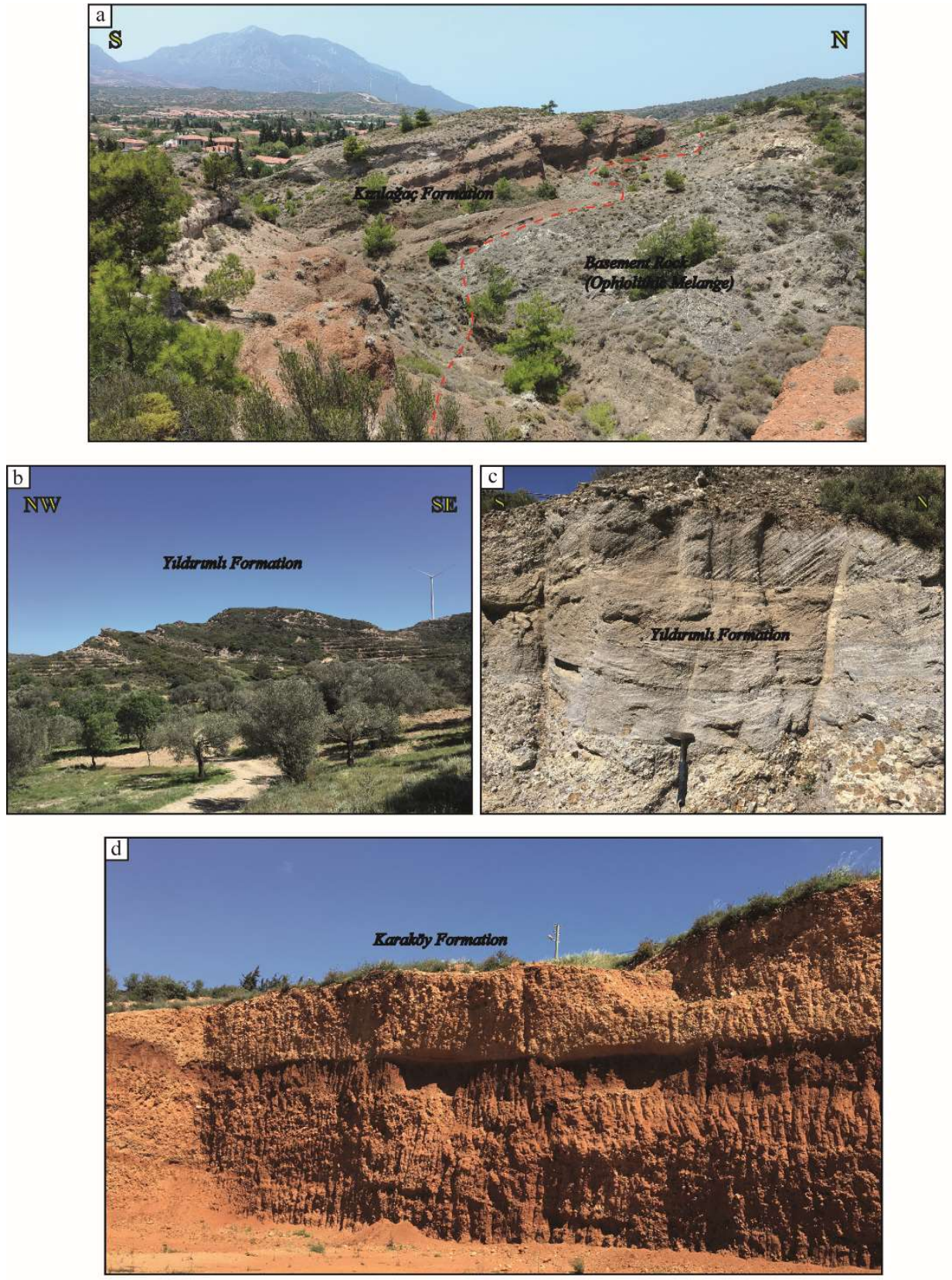

Figure 6: (a) Unconformity plane between basement rocks and south-dipping Kızılağaç Formation (NE of Kızlan village), (b) the South dipping Yıldırımlı Formation, (c) Cross-bedding structure observed in Yıldırımlı Formation, (d) nearly horizontal Karaköy Formation 



\section{CHAPTER 3}

\section{PALEOSTRESS ANALYSIS}

Paleostress analysis is performed in order to reveal the kinematic characteristics of faults and their spatial distributions. To be able to perform paleostress analysis, the first thing to do is collecting fault data sets in the field and gathering those data according to the sampling sites. After that, the paleostress configurations are reconstructed for each sampling site independently. The aim of paleostress reconstruction is to find the fault plane and slickenline orientations and relative sense of movement of the faults. Furthermore, the continuations, orientations and spatial distribution of faults can be mapped. As a result of the analysis, the paleostress orientations and their relative magnitudes are determined by using reduced stress tensor concept, and it helps to understand the kinematic evolution of the area and fault characteristics, which were developed in the study area.

\subsection{Paleostress Analysis from Fault Slip Data}

Paleostress analysis is the estimation of the principal stress orientations using fault slip data collected by the field measurements of fault slip data, and it provides a dynamic interpretation for the kinematic analysis of faults with respect to the tectonic regimes that have affected the area in the past. Slip directions can be inferred from the orientations of frictional grooves or fibrous lineations, slickenlines (Fleuty, 1974; Doblas, 1998). Moreover, slip directions can be inferred also from focal mechanisms of the earthquakes (Angelier, 1984; Gephart and Forsyth, 1984; Carey-Gailhardis and Mercier, 1989).

There are numerous methods which have been developed for the paleostress analysis and also for the separation of multi-deformational stress phases. Graphical and numerical methods have been first demonstrated by Arthaud (1969) and Carey \& 
Brunier (1974) respectively. Graphical methods have further developed as M-plane method by Alexandrowski (1985), Odd-Axis method by Krantz (1988) and RightDihedra method by McKenzie (1969), Angelier and Mechler (1977), Lisle (1987). Graphical methods are concentrated on finding the orientations of the stress tensor for each measurement and they are represented on a unit sphere. They are also useful to separate the heterogeneous data, which may be the result of multiple tectonic regimes, interactions, and reactivation of faults. However, the relative magnitudes of paleostresses cannot be measured directly by using graphical methods. In that manner, numerical methods are more favorable and reliable. Numerical methods are based on the assumption that the slip occurs parallel to the maximum resolved shear stress direction and parallel to the slickenline direction (Wallace, 1951; Bott, 1959). Also, the method assumes a single tectonic event as characterized by one regional homogeneous stress field. This means that a single stress deviator can determine one slip direction on a fault plane which belongs to the faults, moving independently and consistent with this single stress deviator (Will and Powell, 1991).

In this study, the direct inversion method (INDV) of Angelier $(1979,1984,1994)$ was used as a numerical paleostress reconstruction technique based on the reduced stress tensor concept. By using this paleostress reconstruction technique, paleostress orientations and relative paleostress magnitudes were found. In order to apply this method, some assumptions, which are supposed to be valid during faulting are considered. These assumptions are: 1) The fault blocks move independently as a single block along with the maximum resolved shear stress where block rotations are negligible. 2) The direction of maximum resolved shear stress is parallel to the slickenlines that are formed on a planar fault surface (Wallace 1953, Bott 1969 hypothesis). 3) The movement of faults should obey the Mohr-Coulomb failure criterion. In other words, the frictional envelope governs the failure and motion of the faults (Coulomb, 1776; Mohr, 1900). 4) Single-phase of uniform stress field activate the faults. 5) Pore-water pressure does not alter the original properties of faults which 
means that Mohr-Coulomb relationship is not affected by pore-water pressure changes.

Although the application of Angelier's method based on those assumptions previously mentioned above, it is not always possible to idealize and simplify local heterogeneities and some inconsistencies in structures and faults, which are not perfectly planar in some scale such as listric fault geometry does not completely satisfy the assumption accepting that the faults are uniformly dipping planar structures. However, when the previous application and results are taken into consideration, it has been proven that the paleostress reconstructions are consistent and experimentally valid.

The reduced stress tensor concept proposed by Angelier (1984) is a numerical method used to determine the paleostress configuration for a given fault population. The shape of the principle stress ellipsoid can be described by a stress ratio $(\Phi)$ which is equal to $\left(\sigma_{2}-\sigma_{3}\right) /\left(\sigma_{1}-\sigma_{2}\right)$, and it varies between 0 and 1 where $\sigma_{1}>\sigma_{2}>\sigma_{3}$. On the basis of this equation, in areas where stress ratio $(\Phi)$ is equal to 0 (i.e. prolate stress ellipsoid), uniaxial compression condition ( $\sigma_{2}=\sigma_{3}$ ) prevails. In contrast, if the stress ratio $(\Phi)$ is found as 1 (i.e. oblate stress ellipsoid), uniaxial tension condition $\left(\sigma_{1}=\sigma_{2}\right)$ prevails. Else if, the stress condition is tri-axial which all the principal stress magnitudes are different from each other, intermediate principal stress $\left(\sigma_{2}\right)$ is determinative to find the fault orientations. In this case, Anderson's Theory (1951) which implies that the surface of the Earth is a principle plane of stress where all the principle stresses are operating perpendicular to each other, and one of them operates perpendicular to the Earth's surface while the other two operates parallel to it. By this way, after the four unknown of reduced stress tensor found, the kinematic characteristics of the faults based on the shape and the orientation of stress ellipsoid can be determined.

\subsection{Fault Data and Sampling}

The sampling sites were chosen as small as possible and structurally homogeneous to avoid the problems due to relative block and fault interactions (Hancock, 1985). For 
each sampling site, the attitude of the fault plane, as well as the orientation of the slickenlines and the sense of motion along the fault plane, were measured and noted. The orientations of the slickenlines were measured by using eGeo Compass Pro developed by Marc Foi. In addition to these, the geographic locations of the sampling sites and the faults were documented by taking photographs. (Figure 7)
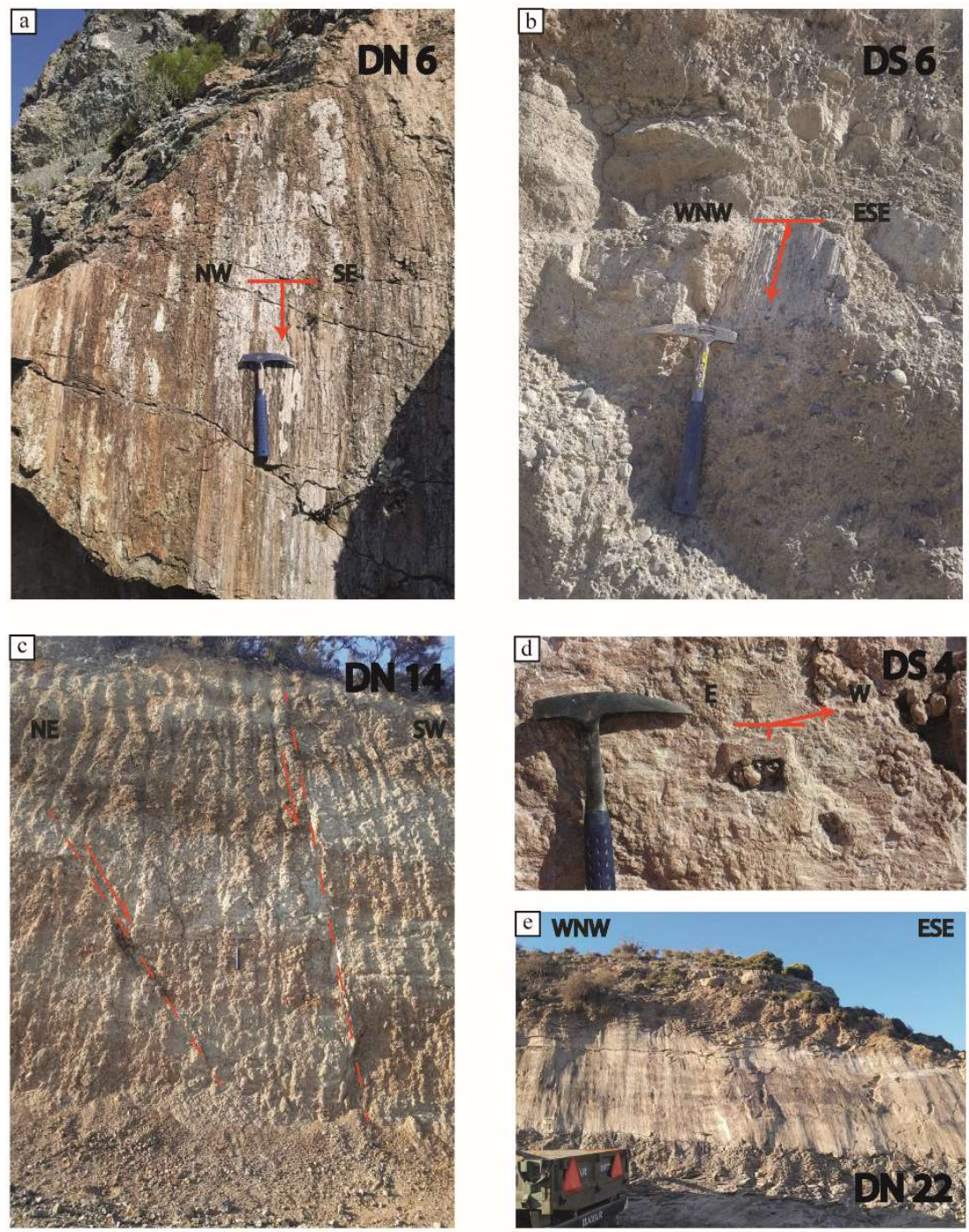

Figure 7: (a) Slickenline lineations on the fault plane located at the northern boundary of the graben, (b) Slickenline lineations on the fault plane located at the southern boundary of the graben, (c) Synsedimentary growth faults developed in the infill sediments of the graben, (d) Strike-slip faults developed as transfer faults, (e) Normal fault developed in the infill sediments of the graben. (Arrows indicate the sense of slip on the fault plane) 
In total, 977 slip data were collected from 44 different fault locations. Whenever it is possible, the overprinting slickenlines were separately measured and the relative order of movement was revealed. However, for some fault data, it is unable to use for the paleostress analysis since no movement sense could be deduced, so that those data were separated from the others.

\subsection{Paleostress Reconstruction Results}

All the data were processed in Win-Tensor (version 5.8.8) which is designed for paleostress reconstruction by Damien Delvaux (Delvaux and Sperner, 2003). The stress tensor calculations are made based on Angelier's reduced stress tensor concept. The obtained results contain the orientation of three principal stress axes, the relative magnitudes of the principal stresses and the R ratio, which corresponds to $\Phi$ in Angelier (1975), as well as the maximum angular deviation for each sampling sites (Appendix A.1). The computational procedure was namely the R-Optimization method in which the orientations of the fault planes and the slickenlines were used. In addition, the software is able to plot each fault planes with slickenline orientations on a stereonet and it allows the user to minimize the angular deviation between the observed and theoretical slip directions by 'optimize' module. During the analysis, the acceptable maximum angular deviation limit kept as $15^{\circ}$ for the computation of a given stress tensor, and the fault planes which exceeding this limit were considered to be suspicious and separated from the main data set since they can represent multiple phases of deformation or stress permutations (Homberg et al., 2002; Hu and Angelier, 2004). Although there are some suspicious data, they only correspond $3 \%$ of the total data, representing the collected data set is consistent among themselves and correspond to a single deformational phase for each fault. 


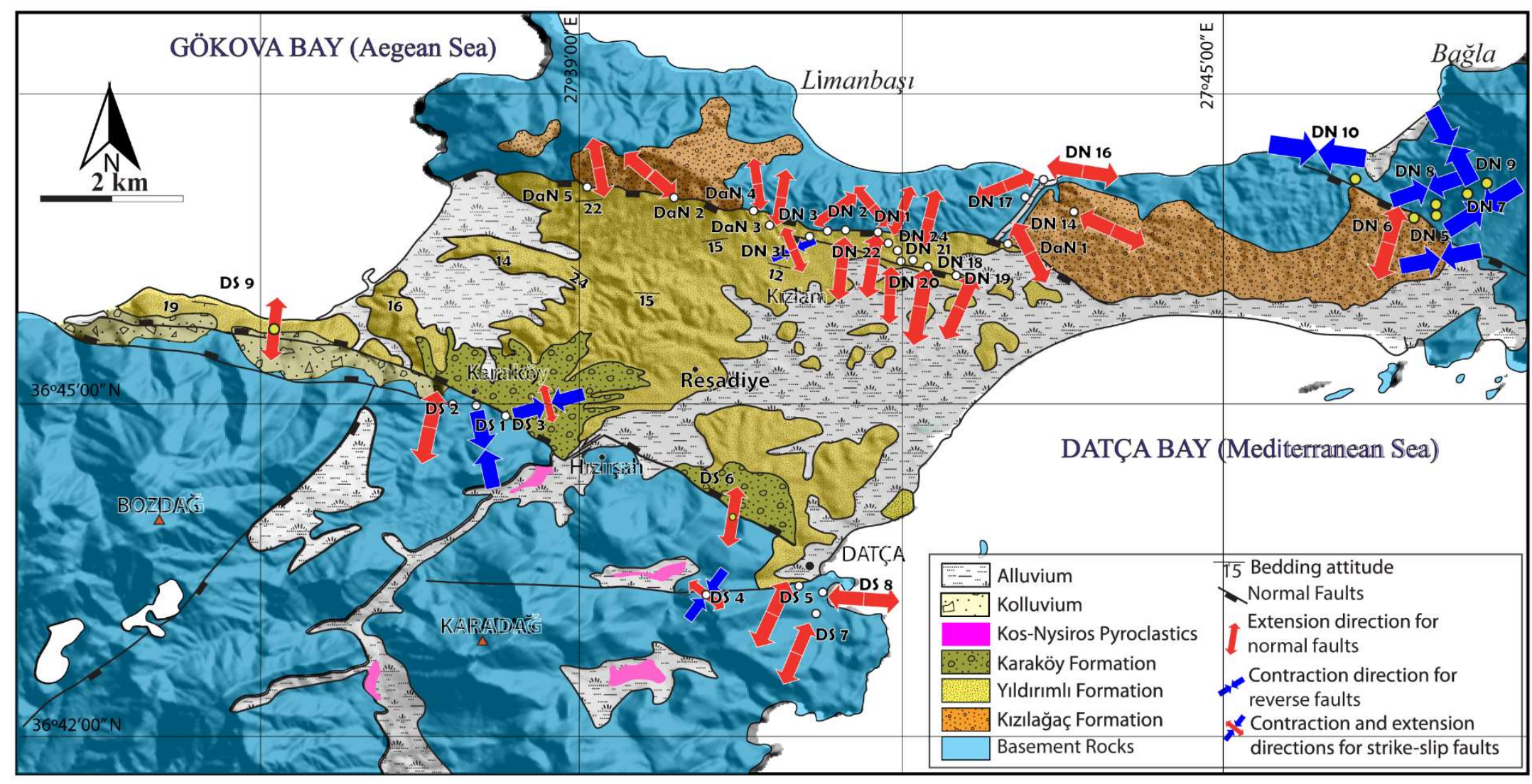

Figure 8: Spatial distribution of the fault sampling sites and paleostress reconstruction results 
The analysis was computed by using 940 slickenline data out of 977 which were collected both from basement rocks and younger units and the lineament map including the paleostress directions has been prepared (Figure 8).

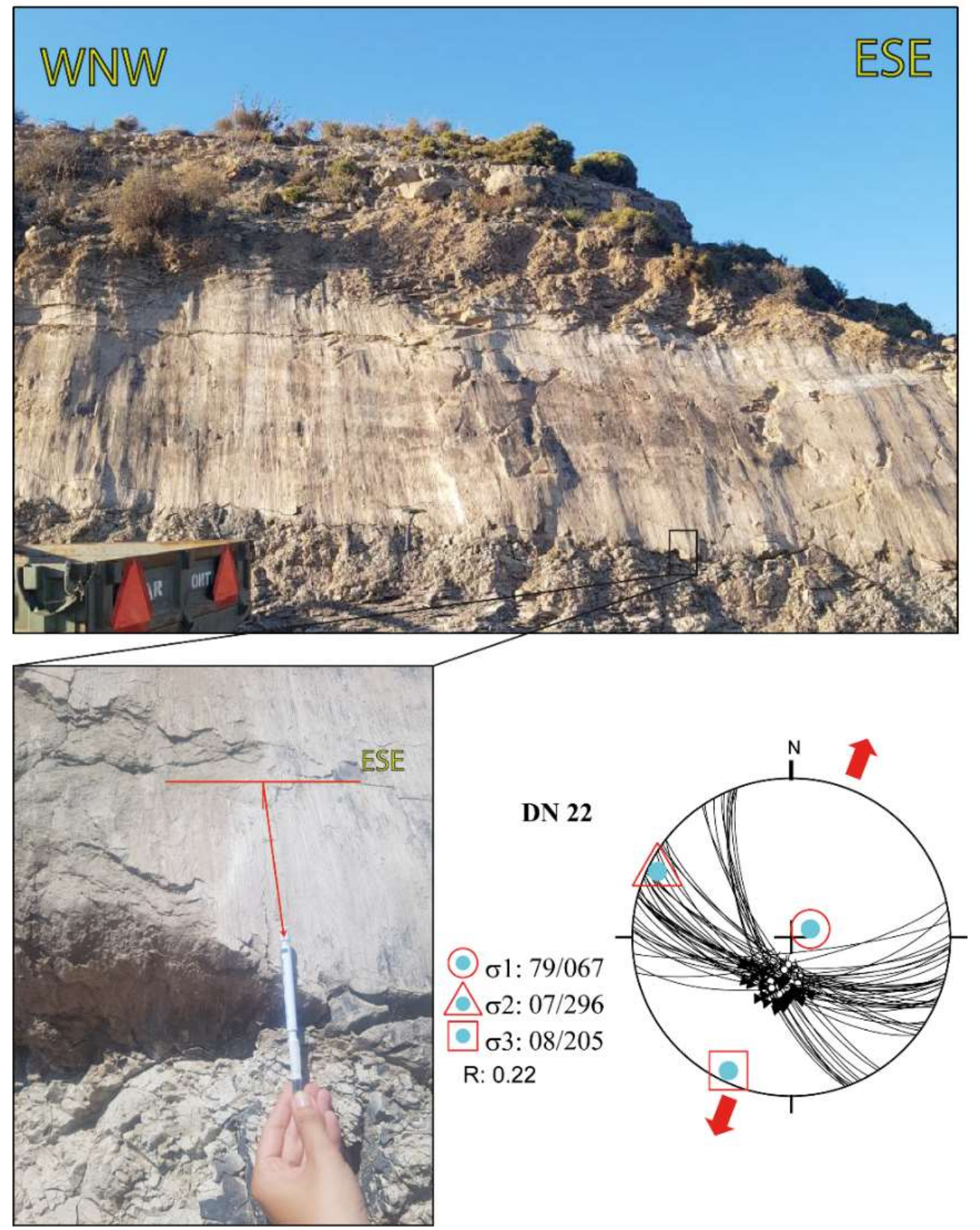

Figure 9: NW-SE-oriented normal fault and its paleostress reconstruction result 
The results show that during the paleotectonic stage, the region has experienced almost N-S and E-W compressional regime. From the obtained paleostress reconstruction results for the younger faults, it can be claimed that the dominant extension direction is almost N-S and it was manifested by WNW-ESE-striking normal faults, which have steeply plunging $\sigma_{1}$ axes, and gently plunging $\sigma_{2}$ and $\sigma_{3}$ axes (Figure 99). The normal faults developed within the basin shows a growth fault properties that implies the deformation took place in the region was synsedimentary. In addition to the normal faults, the faults with a significant amount of dextral strike-slip components were also observed, and the tips of those strike-slip faults terminate against the normal faults, which can be interpreted as transfer faults (Figure 10).

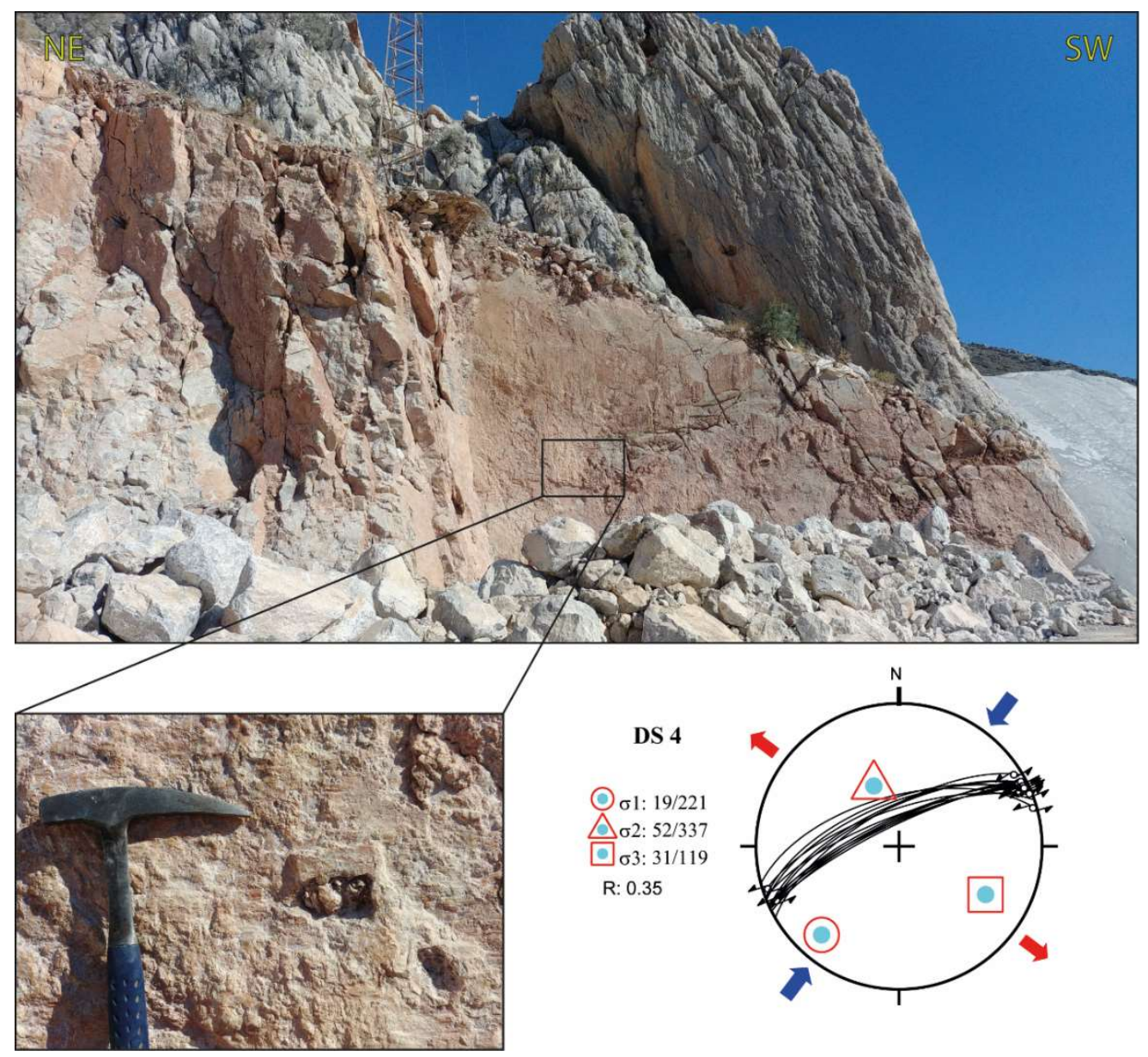

Figure 10: NE-SW-oriented strike-slip fault and its paleostress reconstruction result 


\section{CHAPTER 4}

\section{MAGNETOSTRATIGRAPHY}

\subsection{Introduction}

Sedimentary and volcanic rocks contain small magnetic minerals that could record the direction (declination and inclination) of the Earth's magnetic field at the time of deposition and formation, respectively. If there was no intense heating or alteration in the period after formation, which is the ideal case to be able to capture the directions of the magnetic field, the characteristic remanent magnetization (ChRM) is locked for millions of years and can be measured in rock samples by using paleomagnetism methods. Paleomagnetism has a very wide range of usage, and magnetostratigraphy is one of them.

Magnetostratigraphic dating uses the information about the polarity of the Earth's magnetic field, which is repetitively inverted from 'normal' (north directed) to 'reversed' (south directed), and vice versa. When the obtained precise durations of normal and reversed polarity period, which is so-called 'chrons', is combined with the information obtained from other dating methods, a reference time scale, the Geomagnetic Polarity Time Scale (GPTS), is created. For magnetostratigraphic dating of sedimentary succession, the first step is taking oriented core samples from the measured sedimentary section with $\sim 0.5-5 \mathrm{~m}$ resolution (Opdyke and Channell, 1996). Afterward, the core samples are subjected to various demagnetization procedure in the laboratory to determine the quality and magnetic directions of each sample. After determination of the magnetic directions, a specific polarity pattern is obtained, and then the resulting polarity pattern is compared with the GPTS. Since magnetostratigraphy interrelates the thickness of the sedimentary succession to time, it can be concluded that the magnetostratigraphy is a good method to reconstruct the 
variations in sedimentation rates through time. The detailed information about the concept of magnetostratigraphy and how GPTS was constructed is discussed in the next part.

\subsection{Concept and Definition}

\subsubsection{The Paleomagnetic Signal}

Magnetostratigraphy is an important dating tool for both igneous and sedimentary rocks containing magnetic minerals, which record the Earth's magnetic field by natural magnetic acquisition processes. The Earth's magnetic field is generated in the liquid outer core of the Earth and the dynamo process can be maintained by convective fluid motion. At the surface of the Earth, the field can be described as a dipole field which is equivalent to having a bar magnet at the center of the Earth (Langereis et al., 2010). At first, it was believed that the magnetic field of the Earth was periodically reversed, but after the more results on lava flows was acquired, it became clear that the reversals occur randomly through geological time. It takes several thousands of years, which is fast enough to be able to consider synchronously with the geological time scale. It is still debated that the causes of the field to reverse, but the recent hypothesis suggested that lateral changes in heat flow at the core-mantle boundary play an important role on the magnetic field reversals (Gubbins, 1999). Although the reversals occur randomly, the reversal frequency can be different each time over geological time spans. For example, the reversal frequency has increased from 1 rev/Myr to 5 rev/Myr since $80 \mathrm{Ma}$. In the Cretaceous, no reversals occurred in between 124.5 Ma and $84 \mathrm{Ma}$, and the field maintained the normal polarity for approximately 40 Ma. This Cretaceous Superchron is called Cretaceous Normal Quiet Zone in the ocean-floor magnetic anomaly profiles (Granot, Dyment, \& Gallet, 2012).

The ancient geomagnetic field can be observed in the rocks at the time of deposition or formation. During the rock formations, which the rocks contain magnetic minerals (usually iron oxides or iron sulfides), these magnetic minerals align with the ambient field and lock in the rock system. Thus, they preserve the direction of the field as 
Natural Remanent Magnetization (NRM). There are basically three types of NRM differentiated by the mechanism of paleomagnetic signal acquisition: Thermoremanent magnetization (TRM), chemical remanent magnetization (CRM) and detrital remanent magnetization (DRM).

Thermoremanent magnetization (TRM) is acquired when the magmatic rocks cool below the Curie temperature of its magnetic mineral. As a result of the cooling, the magnetic field at that time is locked in the rock, the mineral is aligned with the magnetic field, and this magnetic remanence can be stable at room temperature for billions of years. A chemical remanent magnetization (CRM) is acquired when the grain of a magnetic mineral grows through the critical blocking volume or grain size, which the field is locked in, and the remanence can be stable for billions of years. When the clasts of magnetic minerals are deposited, the detrital remanent magnetization (DRM) is acquired. Detrital magnetic grains align with the effect of the ambient magnetic field only if they are in the water column or in the soft and watersaturated top layer of the sediments.

\subsubsection{The Geomagnetic Polarity Time Scale}

The marine magnetic anomalies and magnetostratigraphic records are used to construct a 'bar code' pattern of magnetic polarity intervals. First surveys over the ocean basins were carried out in the 1950s, and linear magnetic anomalies parallel to the mid-oceanic ridges were found by using magnetometers towed behind the research vessels (Cox et al., 1963; Heirtzler et al., 1968). The magnetic anomalies resulted from the remanent magnetization of the oceanic crust during the process of cooling. While uprising magma reached the surface of the ocean floor, the constituent ferromagnetic minerals cool below the Curie temperatures of their own, and the newly formed oceanic crust acquire magnetic remanence direction and polarity in the presence of the

ambient geomagnetic field. Alternating normal and reverse polarity is a result of a continuous process of rising and cooling of magma at the ridges. It was also found that 
the magnetic anomaly is symmetric at both sides of the ridges and it provides information about the continuous record of the geomagnetic reversal sequence.

Periods of predominant polarity reversals are called chrons, and the four youngest chrons were named after the leading scientists who worked in paleomagnetism or geomagnetism areas; Brunhes, Matuyama, Gauss and Gilbert. Brunhes was the first who suggested the existence of field reversals while Matuyama has proved this idea. Gauss carried out work on the mathematical expression of the geomagnetic field, and Gilbert discovered the Earth is a big magnet itself. The chron sequences contain short intervals of opposite polarities called sub-chron, and the sub-chrons are named according to the places where they have been found. For example, the Olduvai normal polarity sub-chron within Matuyama reversed polarity chron is named after the Olduvai Gorge (Tanzania), or the Kaena reverse polarity sub-chron within Gauss normal polarity chron is first discovered in Kaena Point (Hawaii) (Langereis et al., 2010).

Older polarity chrons were not named but they numbered according to the anomaly numbers (Heirtzler et al., 1968). Cande and Kent (1992) give the latest development in the chron nomenclature, and they developed a consistent sub-chron nomenclature, which is used as the standard. The most recent revision is made by Cande and Kent (1995) where they adopted the orbitally tuned timescale for the last 5.3 Myr (Shackleton et al., 1990; Hilgen 1991a,b).

\subsection{Methods}

\subsubsection{Sampling}

Samples were collected from predetermined three sections located in the Datça Graben; Datça Lower (DL), Datça Middle (DM) and Datça Upper (DU). A gasolinepowered drilling machine was used to obtain paleomagnetic core samples at a $\sim 1 \mathrm{~m}$. resolution. This sampling resolution was not always feasible because of not being able to preserve the cores of varying lithologies. Since coarser-grained sediments like conglomerate levels are harder to preserve as core samples and yield no reliable 
paleomagnetic signals, layers of finer-grained sediments were chosen for paleomagnetic sampling. Samples were taken mainly from mudstone and siltstone levels, but for some levels, limestone and fine-grained sandstone levels were also preferred. All samples were oriented using a compass for the proceeding measurements and all the bearing and azimuth values were noted. A total of 344 core samples were collected from 102 levels in total; 48 levels, 164 samples from DL, 5 levels, 17 samples from DM and 49 levels, 163 samples from DU. In total, the thickness of the composite Datça section is $\sim 325 \mathrm{~m}$. The thickness for the lower section and the upper section is $150 \mathrm{~m}$ individually while for the middle section, it is $\sim 25 \mathrm{~m}$. Since sedimentary rocks average out paleosecular variations due to relatively slow sedimentation rates, and magnetic signals overall are relatively weaker compared to volcanic rocks (Tauxe, 2010), at least three core samples were tried to take from one level for the results to be reliable. Also, to be sure a geographic or tectonic coordinate system yields more reliable results, bedding tilt was measured at the sites where the strike and dip changes. Afterward, core orientations and bedding tilt measurements were corrected for the present-day declination of about $5^{\circ}$ (Thébault et al., 2016).

\subsubsection{Demagnetization and Measurement}

All paleomagnetic measurements were carried out at Fort Hoofddijk Paleomagnetism Laboratory at Utrecht University. Prior to demagnetization procedure, all core samples were cut to $22 \mathrm{~mm}$ to shape them into suitable sized $\left(\sim 10.5 \mathrm{~mm}^{3}\right)$ core samples for measurements. With the remaining parts of the core samples, thermomagnetic runs were performed by using a horizontal translation-type Curie balance with a noise level of 5.10-9 $\mathrm{Am}^{2}$ (Mullender et al., 1993). For the Curie balance measurements, 11 samples were chosen from all sections; six samples from DL (DL04-07-12-15-31-48), one sample from DM (DM04) and four samples from DU (DU05-27-35-49). This election was made based on the lithological variations of the levels and the results according to the lithology is given in the results part. A total of 11 samples were powdered first, then separately put into a quartz glass sample holder and $\sim 40 \mathrm{mg}$ of the powdered sample was held between quartz wools. After that, the samples were 
placed into a horizontal-type Curie balance measurement device and heating-cooling cycles were started from room temperature to maximum $700{ }^{\circ} \mathrm{C}$ until samples lose their magnetic properties.

Natural remanent magnetizations (NRM) of the samples were acquired by applying both thermal (TH) and alternating field (AF) demagnetization methods. For thermal demagnetization procedure, 102 samples in total were demagnetized by heating in a magnetically shielded oven $(<2.10-8 \mathrm{~T})$ by stepwise increasing temperature with 20 $50{ }^{\circ} \mathrm{C}$ increments starting from room temperature $\left(20^{\circ} \mathrm{C}\right)$ up to a maximum $570{ }^{\circ} \mathrm{C}$. Further heating was prohibited when a clear intensity increase with a random magnetization direction was observed for some samples. After each heating steps, the NRM was measured in three components on a $2 \mathrm{G}$ Enterprises horizontal DC Squid magnetometer with a noise level of 3.10-12 $\mathrm{Am}^{2}$. The measurement procedure was finished when the NRM was reduced to $<10 \%$ of the initial value.

Alternating field (AF) demagnetization was also performed on 102 samples. The samples were manually put into a Helmholtz coil to provide a non-magnetic environment for measurements. Before demagnetization procedure was performed on all samples, 16 trial samples were chosen from lower, middle and upper sections to check whether heating up to $150^{\circ} \mathrm{C}$ would clean the magnetic intensity of the samples caused by the surface oxidation of magnetite at low temperatures, and those samples were demagnetized using a laboratory-built automated measuring device which applied 16 alternating fields with increasing increments of 4-10 mT. After measuring NRM of non-heated samples and heated samples, there was no significant difference among them, which means that the surface oxidation of magnetite was not so obvious to induce the magnetizations. Therefore, 102 samples were demagnetized without heating. Selected samples from all levels were subjected to stepwise increasing alternating field up to a maximum $100 \mathrm{mT}$, and this was achieved by using a $2 \mathrm{G}$ Enterprises DC Squid magnetometer with attached AF demagnetization coils (Mullender et al., 2016). 


\subsection{Results}

\subsubsection{Rock Magnetic Properties}

Most thermomagnetic data show a gradual decrease in intensity up to $\sim 645^{\circ} \mathrm{C}$ and yields an irreversible signal during cooling in between 300 and $645{ }^{\circ} \mathrm{C}$. These behaviors indicate a presence of a titanomagnetite, which is likely to be maghemite $\left.{ }_{\gamma} \mathrm{Fe} 2 \mathrm{O} 3\right)$, which could also be an indication for a high degree of weathering, related to low-temperature oxidation (Dunlop and Özdemir, 1997).

Fine-grained mudstone sample DL12 shows a gradual decrease in magnetization values up to $\sim 250^{\circ} \mathrm{C}$ with only minor changes in the magnetization. Irreversible curves start to develop at around $350{ }^{\circ} \mathrm{C}$, and the large magnetization drops start to occur at that temperature. Furthermore, the inflection point is less clear occurring at around $260{ }^{\circ} \mathrm{C}$, and the critical temperature for the magnetic mineral is $\sim 625{ }^{\circ} \mathrm{C}$ where the magnetization value reaches zero. All these observations indicate the inversion of maghemite $\left({ }_{\gamma} \mathrm{Fe} 2 \mathrm{O} 3\right)$ to hematite $(\alpha \mathrm{Fe} 2 \mathrm{O} 3)$. Caliche sample DM04 has the same dominant magnetic carrier as DL12. For DM04 the inflection point is less observable, which could indicate that the lesser amount of hematite inversion from maghemite. Similarly, limestone sample DU49 shows the same magnetic rock properties when compared to the other samples (Figure 11). 

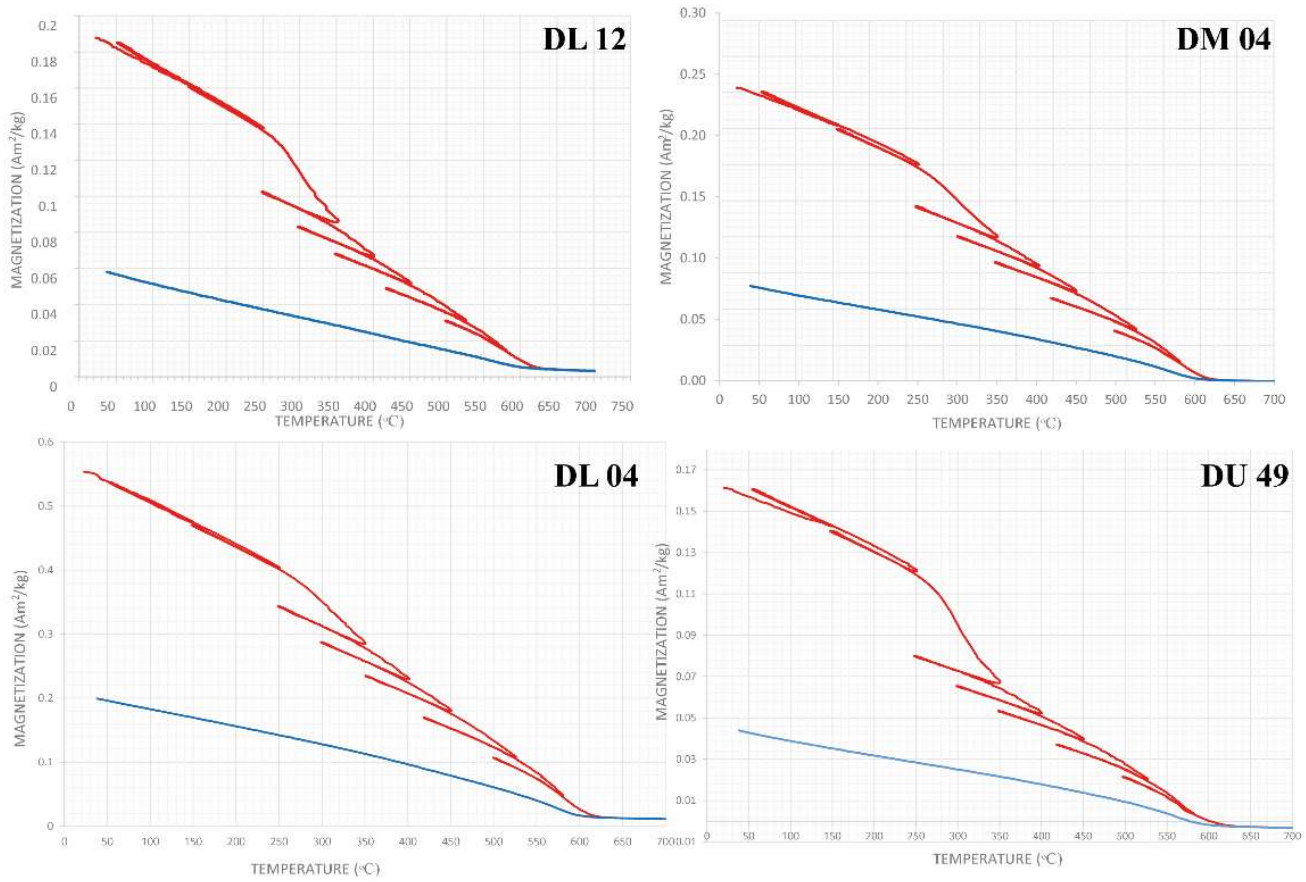

Figure 11: Thermomagnetic curves obtained from Curie Balance measurements for DL04, DL12, DM04, and DU49 levels. (red line represents the heating curve, the blue line represents the cooling curve)

\subsubsection{Demagnetization Results}

Demagnetization diagrams of NRMs were prepared by using orthogonal vector diagrams i.e. Zijderveld diagrams (Zijderveld, 1967). For the interpretations of the diagrams, 'paleomagnetism.org' webpage was used. Characteristic remanent magnetization directions (ChRM) were determined from Zijderveld and Wulff diagrams by taking generally six to eight successive temperature or AF steps, using Principle Component Analysis (PCA) method (Kirschvink, 1980). For the samples in which partial overprint is clear, Great Circle method was used (McFadden and McElhinny, 1988).

The declination directions show a random distribution for all the samples, and most of the inclination values do not exceed $60^{\circ}$ that suggests that during the mechanical drilling of the cores, the magnetic directions have not been aligned parallel to the axis of the drill core. After removal of the first viscous components, the characteristic remanent magnetization $(\mathrm{ChRM})$ of the samples can be identified within the range of 
$250^{\circ} \mathrm{C}$ to $540^{\circ} \mathrm{C}$ and $20 \mathrm{mT}$ to $40 \mathrm{mT}$ for thermal and $\mathrm{AF}$ demagnetization procedures respectively. In some cases, these values can reach up to $570^{\circ} \mathrm{C}$ for thermal demagnetization. For a very limited number of samples, gyro remanent magnetization is observable above $45 \mathrm{mT}$. The mean magnetic intensities are very variable as the values range between $9.4 \times 10^{-9}$ and $552.2 \times 10^{-9} \mathrm{~A} / \mathrm{m}$ around $200^{\circ} \mathrm{C}$ and $20 \mathrm{mT}$.

According to the obtained Zijderveld and Wulff diagrams, the demagnetization results have been grouped into a high quality, medium quality and low-quality group based on the demagnetization trends. The high-quality group shows dominantly linear decay trends towards the origin, and the maximum angular deviation angle (MAD) values are less than $8^{\circ}$, even for some samples, this value reaches to $5^{\circ}$. Their characteristic remanent magnetizations (ChRMs) are plotted in the temperature range between 300 ${ }^{\circ} \mathrm{C}$ and $540{ }^{\circ} \mathrm{C}$. Only $\mathrm{TH}$ samples were assigned to the high-quality group since the demagnetization results are better and show higher stabilities when compared to AF demagnetization results. Also, because of this reason for interpreting the polarity pattern, the priority was given to the TH demagnetization results. The medium quality group contains both thermal and AF samples, which show more scattered decay behavior than the high-quality group samples. Although most of the samples do not completely decay towards the origin, the results still define an unambiguous polarity. The MAD values for medium quality group samples are generally smaller than $20^{\circ}$, and for $\mathrm{TH}$ samples this value is almost $10^{\circ}$ to $15^{\circ}$. The low-quality group contains clustering diagrams without observable decay towards the origin, and the paleomagnetic directions can only be plotted by using less than 4 consecutive data points. The MAD values are far above $15^{\circ}-20^{\circ}$. To make the results more nonobjectionable, those samples were not preferred to use for the construction of polarity pattern, however, for some levels where none of the samples shows high or medium quality behavior, the low-quality samples were used to predict the general polarity pattern of those levels (Figure 12). 


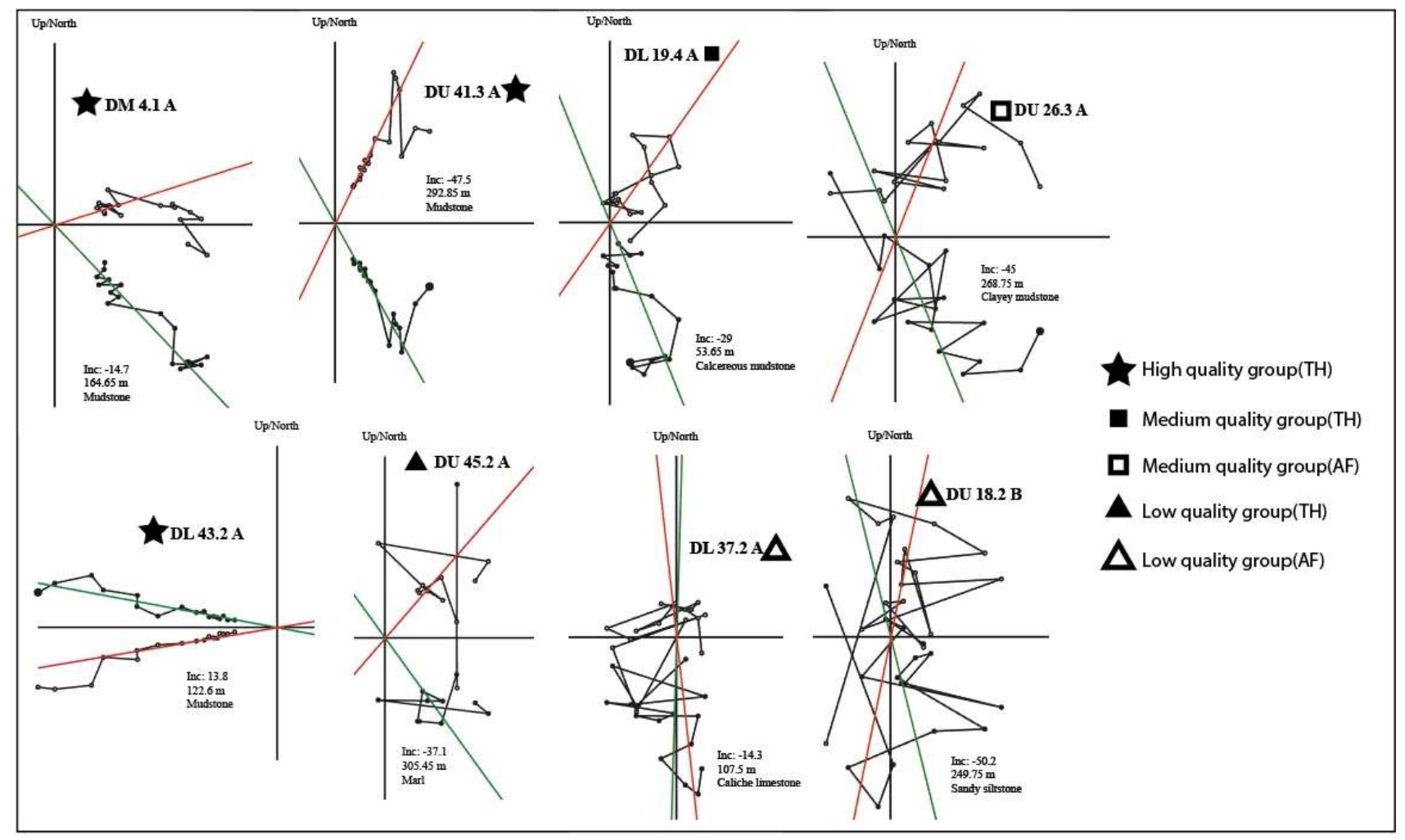

Figure 12: Results of stepwise thermal (TH) and alternative field (AF) demagnetization results on an orthogonal vector endpoint diagrams (Zijderveld, 1967) performed on samples of different lithologies of Yildırımlı Formation. (Red lines to origin represent the best fit of principle component analysis after TH or AF demagnetization procedures, open dot symbols indicate inclination while closed dot symbol indicate declination values after each demagnetization steps) 


\subsubsection{Polarity Pattern}

Polarity pattern representing the inclination values from the stratigraphically ordered demagnetization results has been prepared. Individual polarity zones, including at least three successive levels of similar polarity, has been considered for the whole section. The crossed boxes show the levels, which were not sampled because of the high conglomerate and coarse sand size sediment content since coarse-grained sediments are known for lower quality magnetic signals. According to the obtained inclination values, the magnetostratigraphic section was prepared. It shows that the prominent polarity is reverse especially for the lower and upper Datça (DL and DU) sections. The section starts with a long reverse polarity pattern, is followed by a short normal polarity pattern and ended by second reverse pattern (Figure 13).

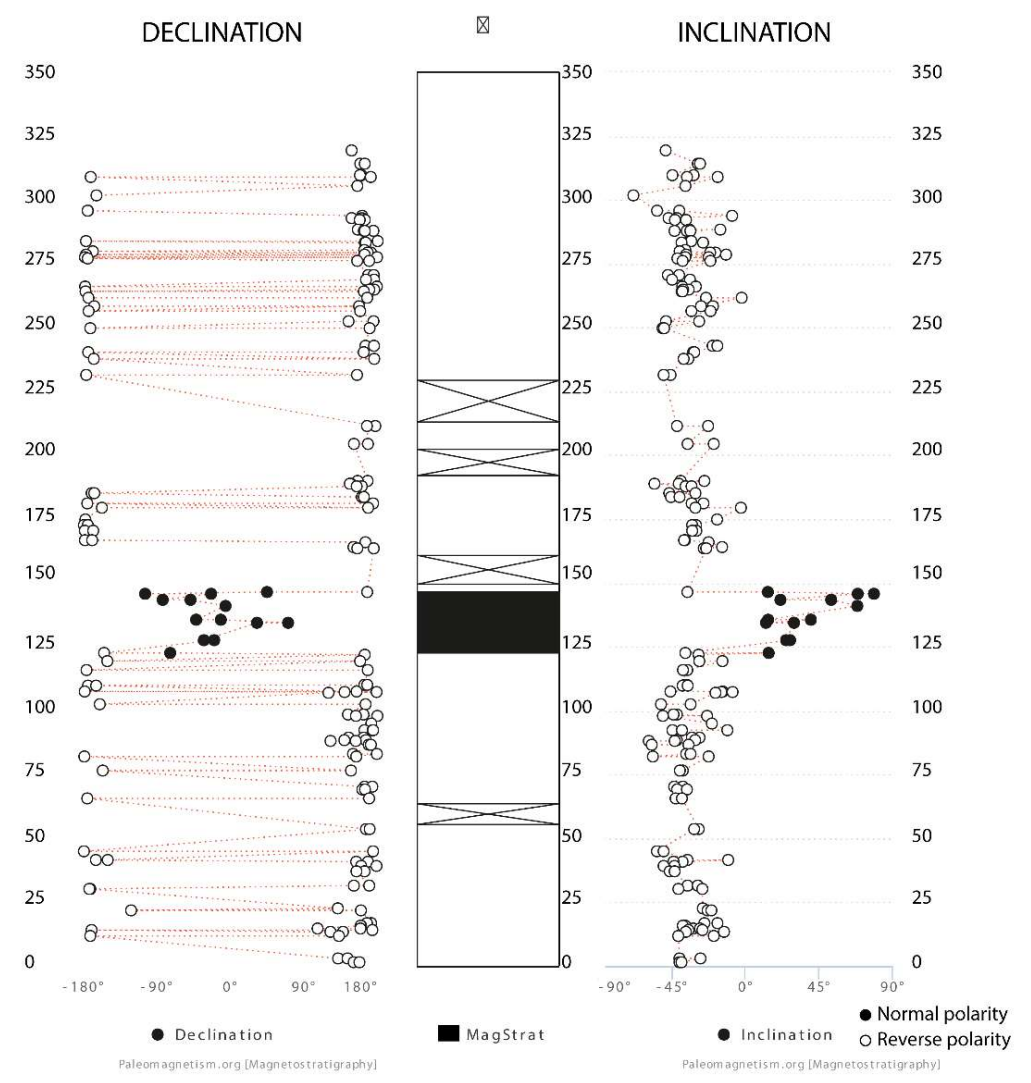

Figure 13: Paleomagnetic directions showing declination and inclination values for Datca section. (Black circles indicate normal polarity, empty circles indicate reverse polarity, crossed boxes indicate unsampled levels) 



\section{CHAPTER 5}

\section{DISCUSSION}

\subsection{Regional Tectonic Implication}

As a result of the observations made in Datça Graben, some inferences can be made. One of them is about the contact relationship between basement rocks and Kızılağaç Formation in the northern part and different extension directions for faults. The Kızılağaç Formation is unconformably overlying the basement rocks (Figure 6a), and it can suggest that the tectonism controlling the formation of Datça Graben was not active during the deposition of Kızılağaç Formation. However, the paleostress results of the syn-sedimentary fault-slip data taken from the Kızılağaç Formation shows that the deposition of Kızılağaç Formation was controlled by NW-SE-directed extensional tectonism manifested by NW-trending normal fault. Above Kızılağaç Formation, the lacustrine sediments started to deposit and they show lateral facies change through the south. During the deposition of these sediments, syn-depositional growth faults have been developed. The paleostress results of those faults give NE-SW-directed extension which is different than the ones measured in the Kız1lağaç Formation. Taking into account all of these, it can be claimed that the Datça region has been subjected to at least two different extensional tectonism since Early Pliocene, and the Datça Graben was controlled by NE-SW-directed extensional tectonism manifested by NW-trending normal faults.

Another inference is about the tectonic evolution of Datça Graben from half-graben to full-graben. One evidence to support this view is that Kızılağaç Formation is only observed in the northern part of the graben and is juxtaposed with the basement rocks while in the southern boundary the basement rocks are juxtaposed with Y1ldirımlı and Karaköy Formations. Also, the northern margin of the graben is topographically less 
steep when it is compared to the southern margin of the graben where the lithologic units are more prone to be eroded. Another observation for the Datça Graben is the dip direction of basin-filling sedimentary units which is through south with an average dip angle of $20^{\circ}$. All these observations empower the existence of full-graben geometry evolved from half-graben which has been formed at the southern boundary of Datça Graben (Figure 14). To be able to make this hypothesis certain, more observations such as paleocurrent studies should be conducted.

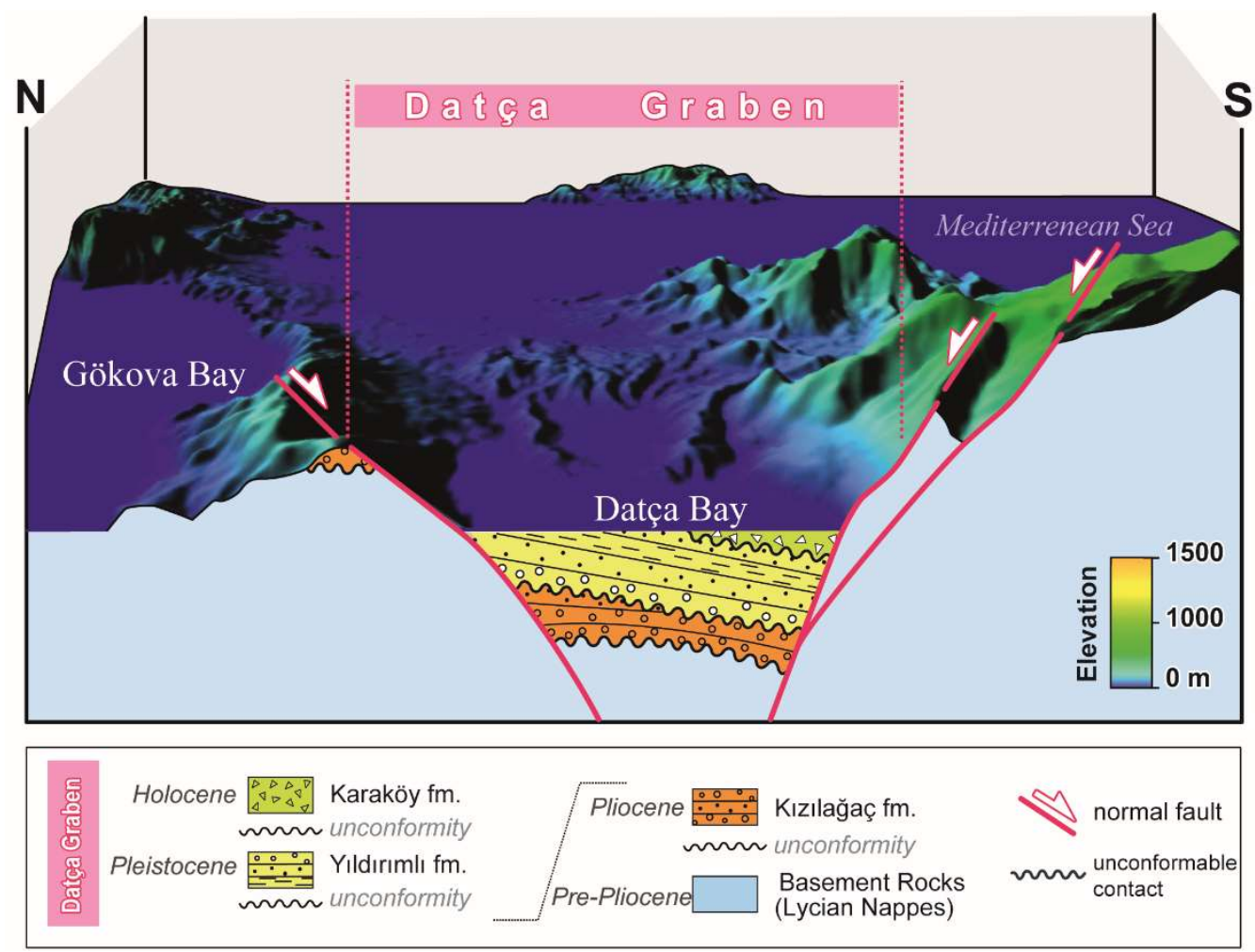

Figure 14: N-S oriented 3D block diagram showing the general cross-section of Datça Graben. (elevation data is generated from 1/25000 scale topographic maps of Turkey)

\subsection{Correlation to Geomagnetic Polarity Time Scale (GPTS)}

The magnetic polarity pattern of the composite Datça section can be correlated to the late Pliocene, early Matuyama in GPTS (Hilgen et al., 2012) when the preserved sedimentation thickness is a function of accommodation space and therefore of 
subsidence (Kircsher et al., 2016). By this assumption, the magnetostratigraphic section would fit best from bottom to top to the $\mathrm{C} 2$ chron with subchrons C2r.2rC2r.1n-C2r.1r with a reversed-normal-reversed polarity pattern. This correlation for the Datça section would indicate that the base of the section correlates roughly to the age of 2.581 Ma. However, the lower limit of the older reversed polarity pattern is not certain. Since the upper and lower boundary of normal polarity pattern is certain, by taking the constant sedimentation rate, the base of the section can be suited to $2.3 \mathrm{Ma}$, and the top of the section can be correlated to the 1.9 Ma. (Figure 15)

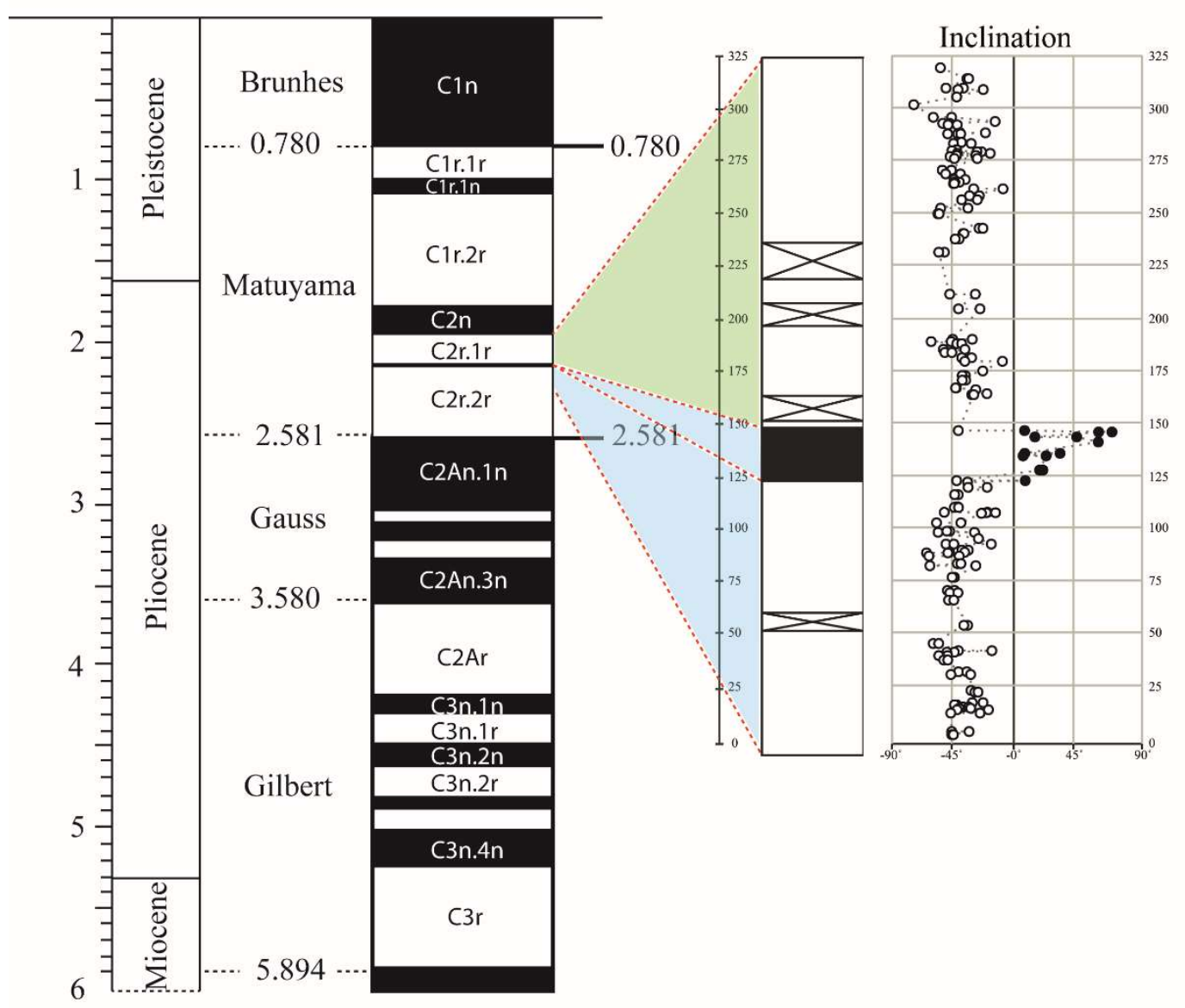

Figure 15: First correlation model to the Geomagnetic Polarity Time Scale (GPTS) (Hilgen et al., 2012) of composite Datça Section. The blue shaded areas have $58 \mathrm{~cm} / \mathrm{Kyr}$, the green shaded area has $82 \mathrm{~cm} / \mathrm{Kyr}$ sedimentation rate. 
A second, alternative correlation model places the base of the Datça section to the lower part of $\mathrm{C} 1 \mathrm{r} .2 \mathrm{r}$ at an age of $1.8 \mathrm{Ma}$. In this model, the characteristic reversednormal-reversed polarity pattern would correlate from bottom to top to $\mathrm{Cl}$ chron consisting C1r.2r-C1r.1n-C1r.1r subchrons (Figure 16). In this case, the composite Datça section can be correlated to early Pleistocene, late Matuyama in GPTS (Hilgen et al., 2012). For the same reason with the first correlation model, the sedimentation rate for normal polarity pattern was measured and it was found as $5 \mathrm{~cm} / \mathrm{Kyr}$. This sedimentation rate does not reflect the reality since the lithologies for the normal polarity zone are mainly reflecting relatively higher energy conditions so that the second alternative model is unsuitable to be used for composite Datça section.

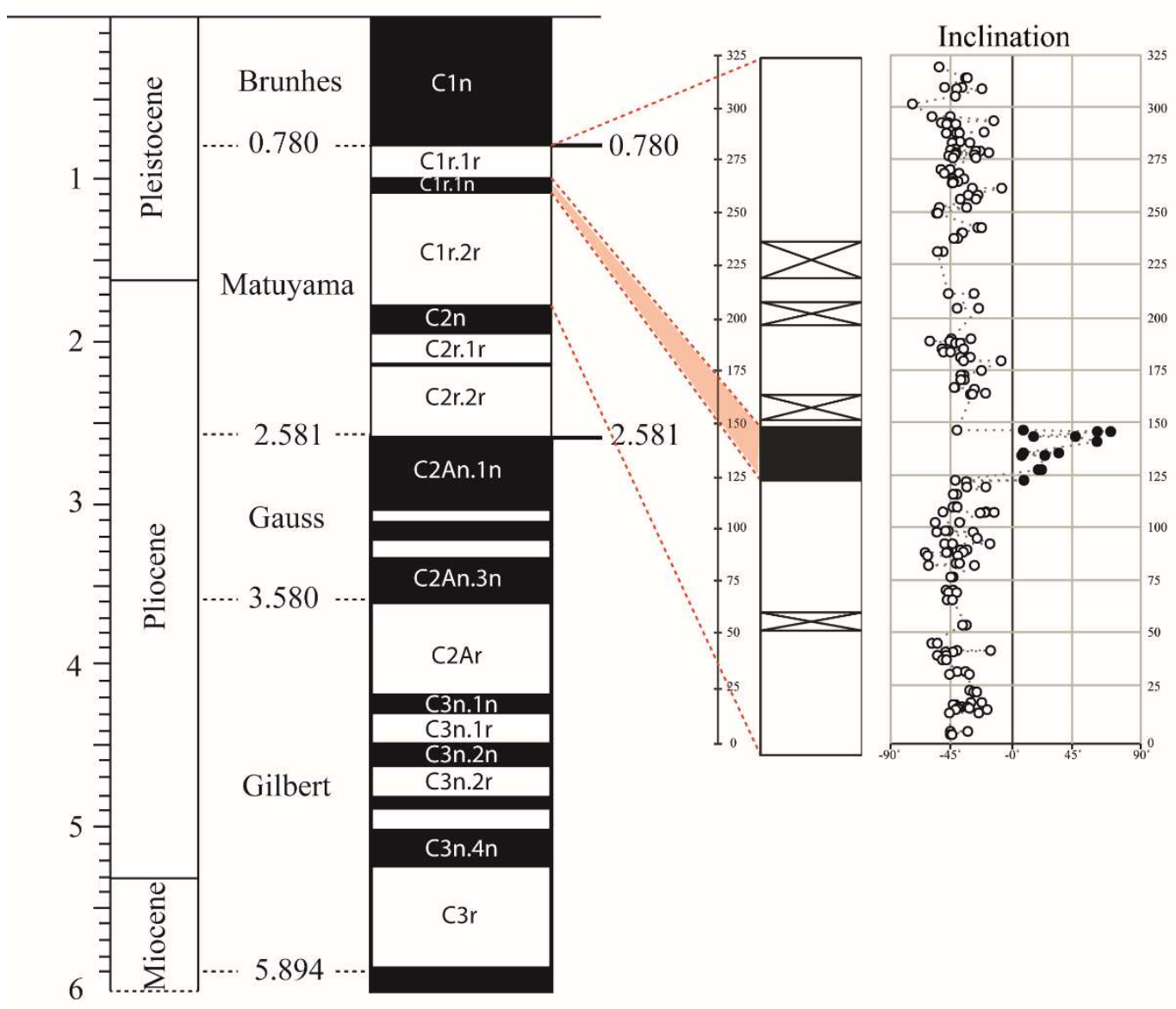

Figure 16: Second correlation model to the Geomagnetic Polarity Time Scale (GPTS) (Hilgen et al., 2012) of composite Datça section. The red shaded area shows the sedimentation rate of $5 \mathrm{~cm} / \mathrm{Kyr}$. 
To make these assumptions more certain, the geochronologic dating has to be done from the tuff layers collected from Datça Lower (DL) and Datça Upper (DU) sections. After the results are given, the exact age interval can be given to the Yildirıml Formation. 



\section{CHAPTER 6}

\section{CONCLUSION}

The study was conducted in Datça, Muğla, SW Turkey, and comprises paleostress analysis of the faults bounding Datça graben from North and South, and magnetostratigraphic dating of Yıldırımlı Formation which was deposited in a first lacustrine environment, then marine environment. The fault orientations and the activities were used to unravel the characteristic deformation style in Datça Graben, and the paleostress analysis was done by using Angelier's reduced stress tensor concept. As a result, the NW-SE, NE-SW, and N-S-directed extensional tectonism were obtained and the NE-SW, NW-SE, and E-W- oriented normal faults controlled the morphology and the neotectonics of the region.

High-resolution magnetostratigraphic dating was performed comprising 344 core samples collected from Yıldırımlı Formation. The high and medium quality drill cores show a very consistent magnetostratigraphic pattern and they were used to represent the magnetostratigraphic column for the three composite sections (DL, DM, and DU). As a result, two different age correlation to the GPTS is suggested. However, the first model is more acceptable for some reasons explained in the discussion part. In the first model, the polarity pattern is correlated to $\mathrm{C} 2 \mathrm{r} .2 \mathrm{r}-\mathrm{C} 2 \mathrm{r} .1 \mathrm{n}-\mathrm{C} 2 \mathrm{r}$.1r subchrons which are correlated to the late Pliocene, Matuyama in GPTS. The age interval for the deposition of Y1ldırımlı Formation is suggested as 2.3 Ma to 1.9 Ma. This age is consistent with the idea suggesting that the age of the Y1ldırıml Formation should be younger than the age of the Kızılağaç Formation which is early Pliocene.

As a result of these, the Datça Graben has been completed its evolution during late Pliocene under the control of NW-trending normal faults at the northern and southern boundaries. 



\section{REFERENCES}

Aleksandrowski, P. (1985). Graphical determination of principal stress directions for slickenside lineation populations: an attempt to modify Artaud's method. Journal of Structural Geology, 7(1), 73-82. doi:10.1016/0191-8141(85)90116-6

Altunel, E. 2003. Impacts of historical seismicity on major ancient coastal cities in southwestern Turkey. CIESM Workshop 2003, 71-76

Allen, S. R., \& Cas, R. A. (2001). Transport of pyroclastic flows across the sea during the explosive, rhyolitic eruption of the Kos Plateau Tuff, Greece. Bulletin of Volcanology, 62(6-7), 441-456. doi:10.1007/s004450000107.

Anderson, E. M. (1951). The dynamics of faulting and dyke formation with applications to Britain. Hafner Pub. Co.

Angelier, J. (1979). Determination of the mean principal directions of stresses for a given fault population. Tectonophysics, 56(3-4), T17-T26. doi:10.1016/00401951(79)90081-7.

Angelier, J. (1984). Tectonic analysis of fault slip data sets. Journal of Geophysical Research: Solid Earth, 89(B7), 5835-5848.

Angelier, J. (1994). Fault slip analysis and paleostress reconstruction. Continental deformation, 53-101.

Angelier, J., Lybéris, N., Le Pichon, X., Barrier, E., \& Huchon, P. (1982). The tectonic development of the hellenic arc and the sea of crete: A synthesis. Tectonophysics, 86(1-3), 159-196. doi:10.1016/0040-1951(82)90066-x.

Angelier, J., \& Mechler, P. (1977). Sur une methode graphique de recherche des contraintes principales egalement utilisables en tectonique et en seismologie : la methode des diedres droits. Bulletin de la Societe Geologique de France, S7-XIX(6), 1309-1318. doi:10.2113/gssgfbull.s7-xix.6.1309.

Arthaud, F. (1969). Methode de determination graphique des directions de raccourcissement, d'allongement et intermediaire d'une population de failles. Bulletin de la Societe Geologique de France, S7-XI(5), 729-737.

Barka, A. A., \& Kadinsky-Cade, K. (1988). Strike-slip fault geometry in Turkey and its influence on earthquake activity. Tectonics, 7(3), 663-684.

Becker-Platen, J.D. 1970. Lithostratigraphische Unterschungen im Kanozoikum Südwest Anatoliens (Türkei) - Kanozoikum und Braunkohlen der Turkei. Hannover: Beihefte zum Geologischen Jahrbuch, 97. 
Bott, M. H. (1959). The Mechanics of Oblique Slip Faulting. Geological Magazine, 96(2), 109-117. doi:10.1017/s0016756800059987

Bozkurt, E. (2001). Neotectonics of Turkey - a synthesis. Geodinamica Acta, 14(13), 3-30. doi:10.1016/s0985-3111(01)01066-X

Cande, S. C., \& Kent, D. V. (1992). A new geomagnetic polarity time scale for the Late Cretaceous and Cenozoic. Journal of Geophysical Research, 97(B10), 13917. doi:10.1029/92jb01202

Cande, S. C., \& Kent, D. V. (1995). Revised calibration of the geomagnetic polarity timescale for the Late Cretaceous and Cenozoic. Journal of Geophysical Research: Solid Earth, 100(B4), 6093-6095. doi:10.1029/94jb03098

Carey, M. E., Brunier, B., (1974). Analyse theorique et numerique d'un modele mecanique elementarie applique a l'etude d'une population de failes. Compte Rendus Hebdomadaines des Seances de l'academie des Sciences, 279, 891-894.

Chaput, E. 1955. Contribution a petude de la faune Pliocene de la Peninsula de Cnide (Turquie), Bll. Scient. Bourgogne, 15, 39-52.

Coulomb, C. A. (1776). Sur une application des regles maximis et minimis a quelques problems de statique, relatives a l'architecture, Acad. Sci. Paris Mem. Math. Phys., 7, 343-382.

Delvaux, D., \& Sperner, B. (2003). New aspects of tectonic stress inversion with reference to the TENSOR program. Geological Society, London, Special Publications, 212(1), 75-100. doi:10.1144/gsl.sp.2003.212.01.06.

DEWEY, J. F., \& ŞENGÖR, A. M. (1979). Aegean and surrounding regions: Complex multiplate and continuum tectonics in a convergent zone. Geological Society of America Bulletin, 90(1), 84.

Dirik, K. 2007. Neotectonic characteristics and seismicity of the Reşadiye Peninsula and surrounding area, Southwest Anatolia, Geol. Bull. of Turkey, 50, 130-149.

Doblas, M. (1998). Slickenside kinematic indicators. Tectonophysics, 295(1-2), 187197. doi:10.1016/s0040-1951(98)00120-6.

Doglioni, C., Agostini, S., Crespi, M., Innocenti, F., Manetti, P., Riguzzi, F., \& Savasci, Y. (2002). On the extension in western Anatolia and the Aegean sea. Journal of the Virtual Explorer, 08. doi:10.3809/jvirtex.2002.00049.

Dunlop, D. J., \& Ozdemir, O. (1997). Rock Magnetism. doi:10.1017/cbo9780511612794.

Ercan, T., Günay, E., Türkecan, A., 1982a. Geology of Bodrum peninsula, Bull. Miner. Res. Explor. Inst. Turk. 97/98, 21-32. 
Ercan, T., Günay, E., Baş, H., Can, B., 1982b. Datça Yarımadasındaki Kuvaterner yaşlı volkanik kayaların stratigrafisi ve yapıs1, MTA Derg., 97/98, 45-56.

Ersoy, Ş. 1990. Stratigraphy and tectonics of the neotectonic units in the Reşadiye (Datça) Peninsula, SW Turkey, IESCA Proceeding, v.2, 116 - 128.

Ersoy, Ş. 1991. Datça (Muğla) Yarımadasının stratigrafisi ve tektoniği, Türkiye Jeoloji Bülteni, C.34, 1-14.

Fleuty, M. J. (1975). Slickensides and slickenlines. Geological Magazine, 112(3), 319-322.

Gençalioğlu-Kuşcu, G., \& Uslular, G. (2018). Geochemical characterization of middistal Nisyros tephra on Datça peninsula (southwestern Anatolia). Journal of Volcanology and Geothermal Research, 354, 13-28. doi:10.1016/j.jvolgeores.2017.12.011

Gephart, J. W., \& Forsyth, D. W. (1984). An improved method for determining the regional stress tensor using earthquake focal mechanism data: Application to the San Fernando Earthquake Sequence. Journal of Geophysical Research, 89(B11), 9305.

Gessner, K., Ring, U., Johnson, C., Hetzel, R., Passchier, C. W., \& Güngör, T. (2001). An active bivergent rolling-hinge detachment system: Central Menderes metamorphic core complex in western Turkey. Geology, 29(7), 611. doi:10.1130/00917613(2001)0292.0.co;2

Govers, R., \& Fichtner, A. (2016). Signature of slab fragmentation beneath Anatolia from full-waveform tomography. Earth and Planetary Science Letters, 450, 10-19. doi:10.1016/j.epsl.2016.06.014

Granot, R., Dyment, J., \& Gallet, Y. (2012). Geomagnetic field variability during the Cretaceous Normal Superchron. Nature Geoscience, 5(3), 220-223. doi:10.1038/ngeo1404

Gubbins, D. (1999). The distinction between geomagnetic excursions and reversals. Geophysical Journal International, 137(1), F1-F4. doi:10.1046/j.1365246x.1999.00810.x

Görür, N., Sengör, A. M., Sakinü, M., Akkök, R., Yiğitbaş, E., Oktay, F. Y., ... Aykol, A. (1995). Rift formation in the Gökova region, southwest Anatolia: implications for the opening of the Aegean Sea. Geological Magazine, 132(6), 637-650. doi: $10.1017 / \mathrm{s} 0016756800018884$

Hancock, P. (1985). Brittle microtectonics: principles and practice. Journal of Structural Geology, 7(3-4), 437-457. doi:10.1016/0191-8141(85)90048-3

Hetzel, R., Passchier, C. W., Ring, U., \& Dora, Ö. O. (1995). Bivergent extension in orogenic belts: The Menderes massif (southwestern Turkey). Geology, 23(5), 455. doi:10.1130/0091-7613(1995)0232.3.co;2 
Homberg, C., Bergerat, F., Philippe, Y., Lacombe, O., \& Angelier, J. (2002). Structural inheritance and cenozoic stress fields in the Jura fold-and-thrust belt (France). Tectonophysics, 357(1-4), 137-158. doi:10.1016/s0040-1951(02)00366-9

Hu, J., \& Angelier, J. (2004). Stress permutations: Three-dimensional distinct element analysis accounts for a common phenomenon in brittle tectonics. Journal of Geophysical Research: Solid Earth, 109(B9), n/a-n/a. doi:10.1029/2003jb002616

Işik, V., \& Tekeli, O. (2001). Late orogenic crustal extension in the northern Menderes massif (western Turkey): evidence for metamorphic core complex formation. International Journal of Earth Sciences, 89(4), 757-765. doi:10.1007/s005310000105

Kaaden, G.V.D. ve Metz, K. 1954. Datça-Muğla-Dalaman çayı (SW Anadolu) arasındaki bölgenin jeolojisi, Türkiye Jeol. Kur. Bült., 5, 1/2, 71-171.

Kapan-Yeşilyurt, S., Taner, G. 2002. Datça yarımadasının geç Pliyosen pelecypoda ve gastropoda faunası ve stratigrafisi (Muğla-Güneybatı Anadolu), MTA Dergisi, 125, 89-120.

Kayan, İ. 1988. Late Holocene sea-level changes on the western Anatolian coast, Palaeogeography, Palaeoclimatology, Palaeoecology, 68, 205-218.

Kaymakc1, N., Aldanmaz, E., Langereis, C., Spell, T. L., Gürer, O. F., \& Zanetti, K. A. (2007). Late Miocene transcurrent tectonics in NW Turkey: evidence from palaeomagnetism and 40Ar-39Ar dating of alkaline volcanic rocks. Geological Magazine, 144(2), 379-392. doi:10.1017/s0016756806003074.

Kirschvink, J. L. (1980). The least-squares line and plane and the analysis of palaeomagnetic data. Geophysical Journal International, 62(3), 699-718. doi:10.1111/j.1365-246x.1980.tb02601.x.

Kocyigit, A., Yusufoglu, H., \& Bozkurt, E. (1999). Evidence from the Gediz graben for episodic two-stage extension in western Turkey. Journal of the Geological Society, 156(3), 605-616.

Langereis, C. G., Krijgsman, W., Muttoni, G., \& Menning, M. (2010). Magnetostratigraphy - concepts, definitions, and applications. Newsletters on Stratigraphy, 43(3), 207-233. doi:10.1127/0078-0421/2010/0043-0207

Le Pichon, X., Angelier, J., \& Sibuet, J. (1982). Plate boundaries and extensional tectonics. Tectonophysics, 81(3-4), 239-256. doi:10.1016/0040-1951(82)90131-7

Lips, A. L., Cassard, D., Sözbilir, H., Yilmaz, H., \& Wijbrans, J. (2001). Multistage exhumation of the Menderes Massif, western Anatolia (Turkey). International Journal of Earth Sciences, 89(4), 781-792. doi:10.1007/s005310000101

Lisle, R. J. (1987). Principal stress orientations from faults: an additional constraints. In Annales Tectonicae, 1(2), 155-158. 
McClusky, S., Balassanian, S., Barka, A., Demir, C., Ergintav, S., Georgiev, I., ... Veis, G. (2000). Global Positioning System constraints on plate kinematics and dynamics in the eastern Mediterranean and Caucasus. Journal of Geophysical Research, 105(B3), 5695-5719. doi:10.1029/1996jb900351.

McElhinny, M. W., \& McFadden, P. L. (1999). Paleomagnetism: Continents and Oceans. Amsterdam, Netherlands: Elsevier.

McFadden, P., \& McElhinny, M. (1988). The combined analysis of remagnetization circles and direct observations in palaeomagnetism. Earth and Planetary Science Letters, 87(1-2), 161-172. doi:10.1016/0012-821x(88)90072-6.

McKenzie, D. (1978). Active tectonics of the Alpine--Himalayan belt: the Aegean Sea and surrounding regions. Geophysical Journal International, 55(1), 217-254. doi:10.1111/j.1365-246x.1978.tb04759.x

McKenzie, D. P. (1969). The relation between fault plane solurions for earthquakes and the directions of the principal stresses. Bulletin of Seismological Society of America, 59(2), 591-601.

Meulenkamp, J., Wortel, M., Van Wamel, W., Spakman, W., \& Hoogerduyn Strating, E. (1988). On the Hellenic subduction zone and the geodynamic evolution of Crete since the late Middle Miocene. Tectonophysics, 146(1-4), 203-215. doi:10.1016/0040-1951(88)90091-1.

Mohr, O. (1900). Welche Umstande bedingen die Elastizitatsgrenze und den Bruch eines Materials. Zeitschrift des Vereins Deutscher Ingenieure, 46(1524-1530), 15721577.

Moores, E. M., Robinson, P. T., Malpas, J., \& Xenophonotos, C. (1984). Model for the origin of the Troodos massif, Cyprus, and other mideast ophiolites. Geology, 12(8), 500. doi:10.1130/0091-7613(1984)122.0.co;2

Mullender, T. A., Velzen, A. J., \& Dekkers, M. J. (1993). Continuous drift correction and separate identification of ferrimagnetic and paramagnetic contributions in thermomagnetic runs. Geophysical Journal International, 114(3), 663-672. doi:10.1111/j.1365-246x.1993.tb06995.x

Opdyke, N. D., \& Channell, J. E. (1996). Laboratory Techniques. International Geophysics, 49-73. doi:10.1016/s0074-6142(06)80006-9

Orombelli, G.; Lozej, G.P.; Rossi, L.A. ve Desio, A., 1967, Preliminary notes on the geology of the Datça peninsula (SW Turkey): Accad. Naz. dei Linç. 8, 42, 830-841.

Özdemir, Ö., \& Dunlop, D. J. (1988). Correction to "Crystallization remanent magnetization during the transformation of maghemite to hematite" by Özden Özdemir and David J. Dunlop. Journal of Geophysical Research, 93(B10), 12216. doi:10.1029/jb093ib10p12216. 
Philippsion, A. 1915. Reisen und Forshungen im westlichien Kleinasien, 5: Karien südliches Maander und das Westliche Lykien. Erg. Heft 183 zu Petermanns Mitteilungen, Gotha

Pichon, X. L., \& Angelier, J. (1979). The hellenic arc and trench system: A key to the neotectonic evolution of the eastern mediterranean area. Tectonophysics, 60(1-2), 142. doi:10.1016/0040-1951(79)90131-8

Pichon, X. L., \& Angelier, J. (1979). The hellenic arc and trench system: A key to the neotectonic evolution of the eastern mediterranean area. Tectonophysics, 60(1-2), 142. doi:10.1016/0040-1951(79)90131-8

Pitman, W. C., Herron, E. M., \& Heirtzler, J. R. (1968). Magnetic anomalies in the Pacific and sea floor spreading. Journal of Geophysical Research, 73(6), 2069-2085. doi:10.1029/jb073i006p02069

Ring, U., Johnson, C., Hetzel, R., \& Gessner, K. (2003). Tectonic denudation of a Late Cretaceous-Tertiary collisional belt: regionally symmetric cooling patterns and their relation to extensional faults in the Anatolide belt of western Turkey. Geological Magazine, 140(4), 421-441. doi:10.1017/s0016756803007878

Rossi, L.A., 1966, La geologia della Peninsula di Datça (Turchia): Doktora Tezi, Milano Üniv., İtalya, 184 s. Rittmann, A., 1952, Nomenclature of Volcanic rocks: Bull. Volcan., 12, 75-102

Royden, L. H. (1993). The tectonic expression slab pull at continental convergent boundaries. Tectonics, 12(2), 303-325. doi:10.1029/92tc02248

Sengör, A. M. (1979). The North Anatolian transform fault: its age, offset and tectonic significance. Journal of the Geological Society, 136(3), 269-282. doi:10.1144/gsjgs.136.3.0269

Sengör, A. M., Satir, M., \& Akkök, R. (1984). Timing of tectonic events in the Menderes Massif, western Turkey: Implications for tectonic evolution and evidence for pan-African basement in Turkey. Tectonics, 3(7), 693-707. doi:10.1029/tc003i007p00693

Sengör, A. M., Görür, N., \& Şaroğlu, F. (1985). Strike-slip faulting and related basin formations in zones of tectonic escape: Turkey as a case study. Strike-Slip Deformation, Basin Formation, and Sedimentation, 227-264

Seyitoglu, G., Isik, V., \& Cemen, I. (2004). Complete Tertiary exhumation history of the Menderes massif, western Turkey: an alternative working hypothesis. Terra Nova, 16(6), 358-364. doi:10.1111/j.1365-3121.2004.00574.x

Seyitolu, G., \& Scott, B. (1991). Late Cenozoic crustal extension and basin formation in west Turkey. Geological Magazine, 128(2), 155-166. doi:10.1017/s0016756800018343 
Seyitolu, G., \& Scott, B. C. (1992). The age of the Büyük Menderes graben (west Turkey) and its tectonic implications. Geological Magazine, 129(2), 239-242. doi:10.1017/s001675680000830x

Smith, P. E., York, D., Chen, Y., \& Evensen, N. M. (1996). Single crystal Ar-Ar dating of a Late Quaternary paroxysm on Kos, Greece: Concordance of terrestrial and marine ages. Geophysical Research Letters, 23(21), 3047-3050.

Tauxe, L. (n.d.). Magnetostratigraphy. Encyclopedia of Earth Science, 740-746. doi:10.1007/0-387-30752-4_92

Taymaz, T., Jackson, J., \& McKenzie, D. (1991). Active tectonics of the north and central Aegean Sea. Geophysical Journal International, 106(2), 433-490. doi:10.1111/j.1365-246x.1991.tb03906.x

Taymaz, T., Yilmaz, Y., \& Dilek, Y. (2007). The geodynamics of the Aegean and Anatolia: introduction. Geological Society, London, Special Publications, 291(1), 116. doi:10.1144/sp291.1

Tintant, H., 1954, Etudes sur la microfaune du Neogene de Turquie: 1-La Microfaune du Pliocene de Datça: Bull. Scient. Bourgogne, 14, 185-208

Wallace, R. E. (1951). Geometry of Shearing Stress and Relation to Faulting. The Journal of Geology, 59(2), 118-130. doi:10.1086/625831.

Willmann, R. 1981. Evolution, Systematik und stratigraphische Bedeutung der neogenen Süßwassergastropoden von Rhodos und Kos Ägäis, Palaeontographica A, 174, 10-235, Stuttgart.

Willmann, R. 1985. Responses of the Plio-Pleistocene freshwater gastropods of Kos (Greece, Aegean sea) to environmental changes, Sediment Lect. Notes Earth Sci., 1, 295-321.

Zijderveld, J. (1967). The natural remanent magnetizations of the exeter volcanic traps (Permian, Europe). Tectonophysics, 4(2), 121-153. doi:10.1016/00401951(67)90048-0. 



\section{APPENDICES}

\section{A. Paleostress Reconstruction Results}

\begin{tabular}{|c|c|c|c|c|c|c|c|c|c|c|}
\hline \multirow{2}{*}{\begin{tabular}{|l|} 
Site ID \\
DN1 \\
\end{tabular}} & \multirow{2}{*}{\begin{tabular}{|r|} 
Longitude \\
27.68923 \\
\end{tabular}} & \multirow{2}{*}{\begin{tabular}{r|} 
Lattitude \\
36.77798 \\
\end{tabular}} & \multirow{2}{*}{\begin{tabular}{|r|} 
n/nt \\
$54 / 54$ \\
\end{tabular}} & \multicolumn{2}{|c|}{$\begin{array}{c}\sigma 1 \\
\text { dip/dip-dir }\end{array}$} & \multicolumn{2}{|c|}{$\begin{array}{c}\sigma 2 \\
\text { dip/dip-dir }\end{array}$} & \multicolumn{2}{|c|}{$\begin{array}{c}\sigma 3 \\
\text { dip/dip-dir }\end{array}$} & \multirow{2}{*}{\begin{tabular}{c|}
$\mathbf{R}$ \\
0.51 \\
\end{tabular}} \\
\hline & & & & 60 & 0 & 13 & 247 & 26 & 151 & \\
\hline DN1L & 27.68915 & 36.77797 & $23 / 23$ & 9 & 187 & 54 & 85 & 34 & 284 & 0.53 \\
\hline DN2 & 27.68763 & 36.77874 & $18 / 18$ & 54 & 59 & 22 & 296 & 28 & 194 & 0.49 \\
\hline DN3 & 27.68738 & 36.77824 & $19 / 19$ & 55 & 6 & 20 & 127 & 27 & 228 & 0.5 \\
\hline DN3L & 27.68743 & 36.77826 & $14 / 14$ & 4 & 50 & 66 & 150 & 24 & 319 & 0.52 \\
\hline DN6 & 27.68294 & 36.77812 & $54 / 54$ & 71 & 360 & 4 & 100 & 18 & 192 & 0.51 \\
\hline DN6L & 27.68276 & 36.77819 & $12 / 12$ & 24 & 332 & 20 & 232 & 58 & 107 & 0.5 \\
\hline DN7 & 27.77714 & 36.78153 & $13 / 13$ & 4 & 66 & 21 & 157 & 69 & 326 & 0.5 \\
\hline DN7N & 27.77857 & 36.78191 & $27 / 27$ & 72 & 133 & 5 & 239 & 18 & 330 & 0.5 \\
\hline DN7S & 27.77853 & 36.78194 & $25 / 25$ & 21 & 187 & 52 & 307 & 30 & 84 & 0.5 \\
\hline DN8 & 27.77861 & 36.78202 & $14 / 14$ & 1 & 134 & 36 & 225 & 54 & 42 & 0.48 \\
\hline DN72 & 27.77694 & 36.78144 & $24 / 24$ & 13 & 135 & 7 & 227 & 75 & 344 & 0.51 \\
\hline \begin{tabular}{|l|} 
DN73 \\
\end{tabular} & 27.77694 & 36.78144 & $11 / 11$ & 24 & 69 & 10 & 335 & 64 & 223 & 0.49 \\
\hline DN74 & 27.77694 & 36.78145 & $17 / 18$ & 20 & 150 & 2 & 241 & 70 & 337 & 0.5 \\
\hline DN75 & 27.77683 & 36.78141 & $14 / 14$ & 23 & 191 & 6 & 283 & 67 & 27 & 0.53 \\
\hline DN76 & 27.77791 & 36.78176 & $23 / 23$ & 18 & 85 & 11 & 351 & 69 & 230 & 0.49 \\
\hline DN9 & 27.77875 & 36.78216 & $31 / 31$ & 9 & 290 & 11 & 21 & 75 & 63 & 0.6 \\
\hline DN10 & 27.77222 & 36.76994 & $30 / 30$ & 2 & 255 & 29 & 346 & 61 & 161 & 0.47 \\
\hline DN14 & 27.72613 & 36.77899 & $23 / 23$ & 80 & 97 & 2 & 354 & 10 & 263 & 0.5 \\
\hline DN16 & 27.71789 & 36.78385 & $24 / 24$ & 42 & 218 & 44 & 9 & 15 & 114 & 0.5 \\
\hline DN17 & 27.71791 & 36.78212 & $10 / 10$ & 80 & 19 & 8 & 173 & 4 & 263 & 0.49 \\
\hline DN18 & 27.70132 & 36.77242 & $130 / 130$ & 69 & 332 & 13 & 99 & 16 & 193 & 0.5 \\
\hline DN19 & 27.70540 & 36.77050 & $23 / 23$ & 72 & 191 & 3 & 290 & 18 & 21 & 0.51 \\
\hline DN20 & 27.69802 & 36.77350 & $25 / 25$ & 72 & 3 & 3 & 103 & 17 & 194 & 0.49 \\
\hline DN21 & 27.69693 & 36.77251 & $17 / 17$ & 73 & 10 & 1 & 104 & 17 & 195 & 0.46 \\
\hline DN22 & 27.69470 & 36.77524 & $50 / 50$ & 68 & 41 & 4 & 301 & 21 & 209 & 0.39 \\
\hline DN23 & 27.72611 & 36.77894 & $12 / 12$ & 56 & 53 & 7 & 153 & 33 & 248 & 0.5 \\
\hline DN24 & 27.72617 & 36.77892 & $9 / 9$ & 38 & 63 & 41 & 289 & 25 & 175 & 0.5 \\
\hline DaN1 & 27.71132 & 36.77264 & $19 / 19$ & 66 & 41 & 14 & 276 & 19 & 181 & 0.35 \\
\hline DaN3 & 27.67846 & 36.77813 & $13 / 13$ & 72 & 19 & 2 & 285 & 18 & 194 & 0.5 \\
\hline DaN4 & 27.67775 & 36.77939 & $14 / 14$ & 78 & 310 & 5 & 62 & 11 & 153 & 0.48 \\
\hline DaN5 & 27.64999 & 36.78311 & $12 / 12$ & 43 & 79 & 46 & 272 & 6 & 175 & 0.5 \\
\hline DS1 & 27.63298 & 36.74989 & $9 / 9$ & 40 & 304 & 19 & 197 & 44 & 88 & 0.59 \\
\hline DS2 & 27.63204 & 36.75002 & $17 / 17$ & 37 & 112 & 51 & 274 & 9 & 15 & 0.49 \\
\hline DS3 & 27.63611 & 36.74728 & $10 / 10$ & 6 & 281 & 71 & 29 & 18 & 190 & 0.5 \\
\hline DS4 & 27.66302 & 36.72031 & $30 / 30$ & 8 & 211 & 72 & 325 & 17 & 118 & 0.5 \\
\hline DS5 & 27.68348 & 36.72166 & $9 / 9$ & 54 & 251 & 18 & 135 & 30 & 34 & 0.48 \\
\hline DS6 & 27.68509 & 36.71833 & $33 / 33$ & 78 & 77 & 10 & 287 & 6 & 196 & 0.51 \\
\hline DS7 & 27.68554 & 36.71815 & $20 / 20$ & 75 & 69 & 9 & 304 & 12 & 212 & 0.49 \\
\hline DS8 & 27.68525 & 36.72058 & $12 / 12$ & 74 & 191 & 11 & 325 & 12 & 57 & 0.34 \\
\hline DS8S & 27.68524 & 36.72058 & $23 / 23$ & 15 & 205 & 60 & 87 & 25 & 302 & 0.5 \\
\hline DS9 & 27.63334 & 36.76889 & $18 / 18$ & 54 & 59 & 22 & 296 & 28 & 194 & 0.49 \\
\hline
\end{tabular}



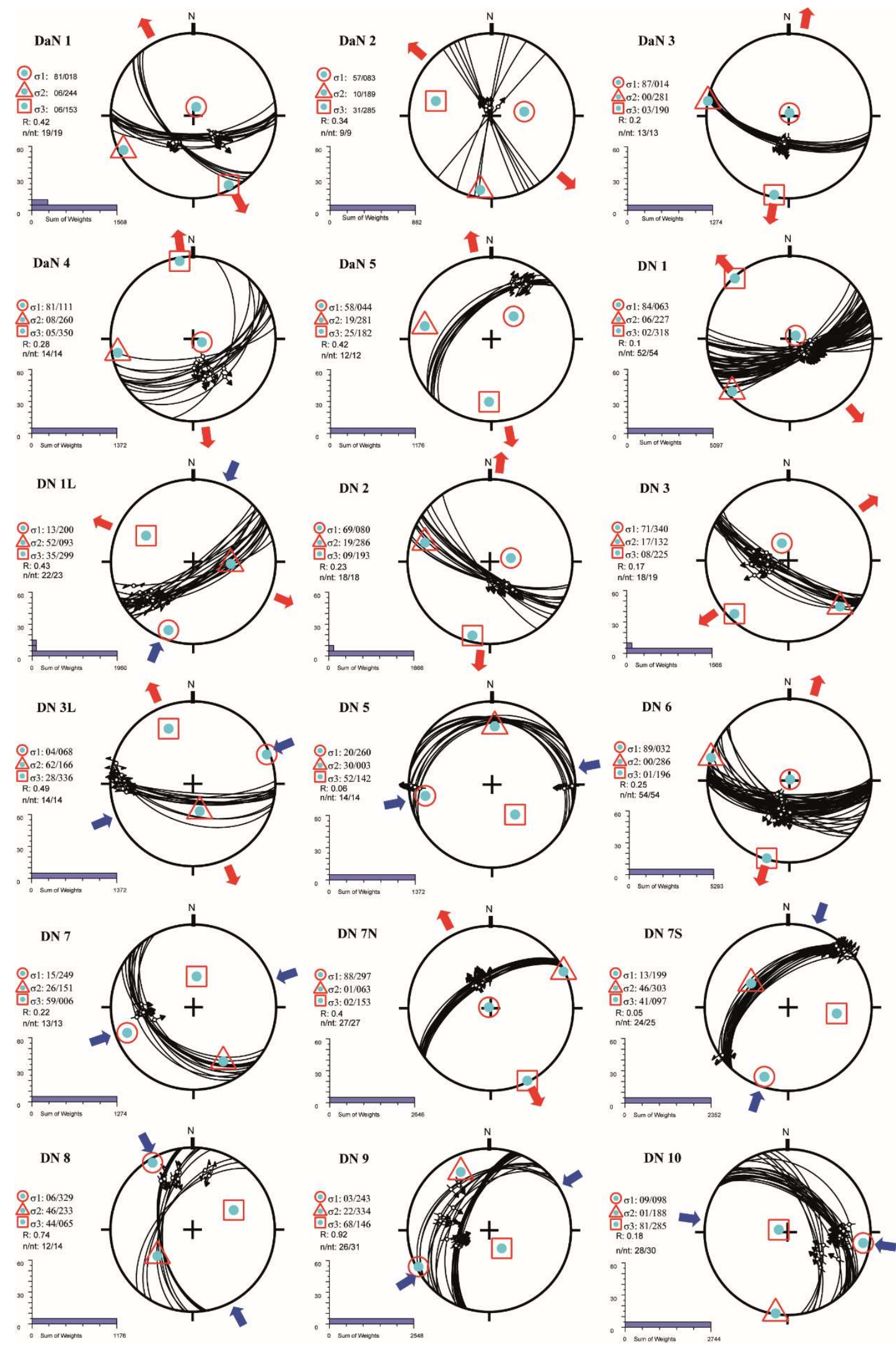

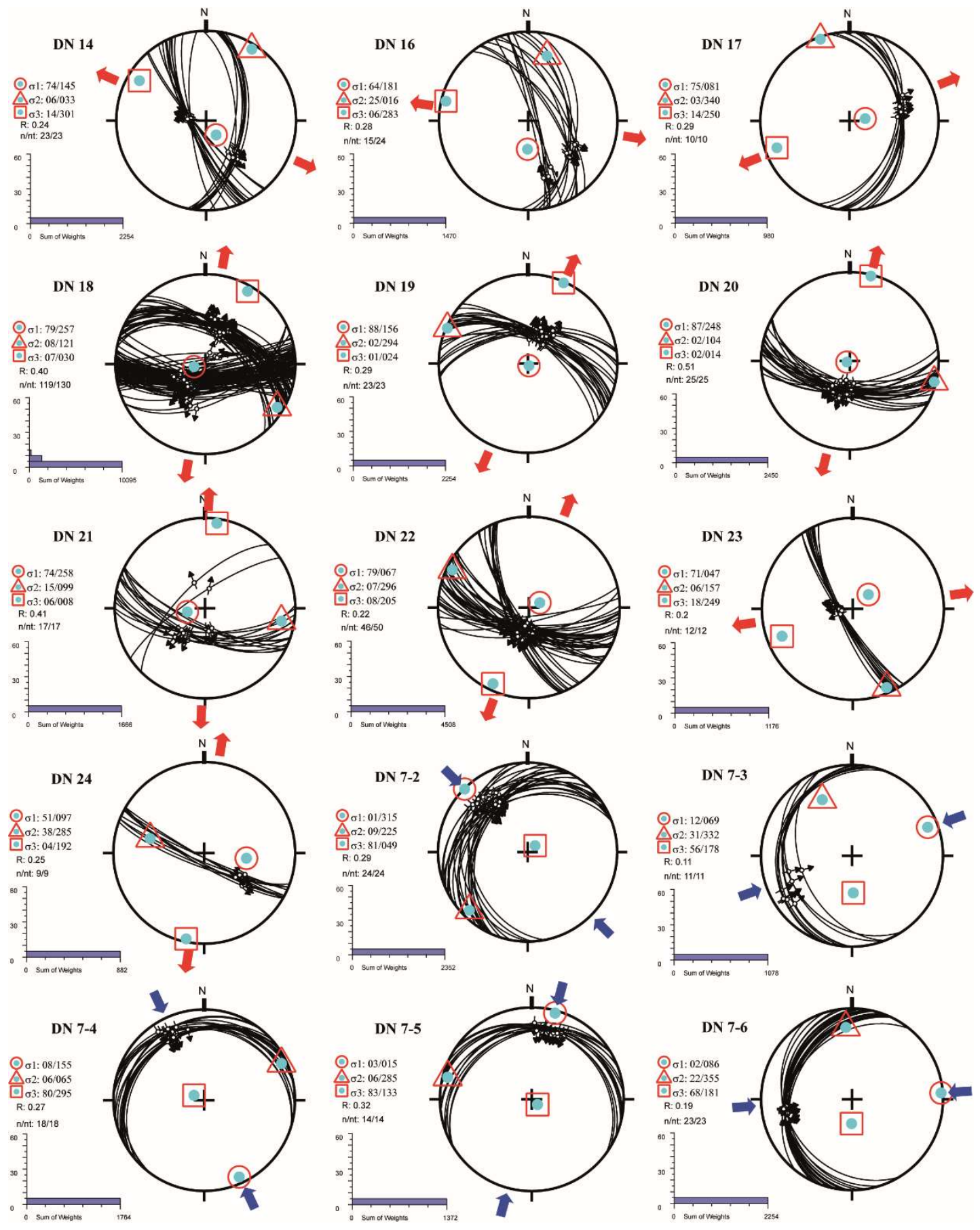

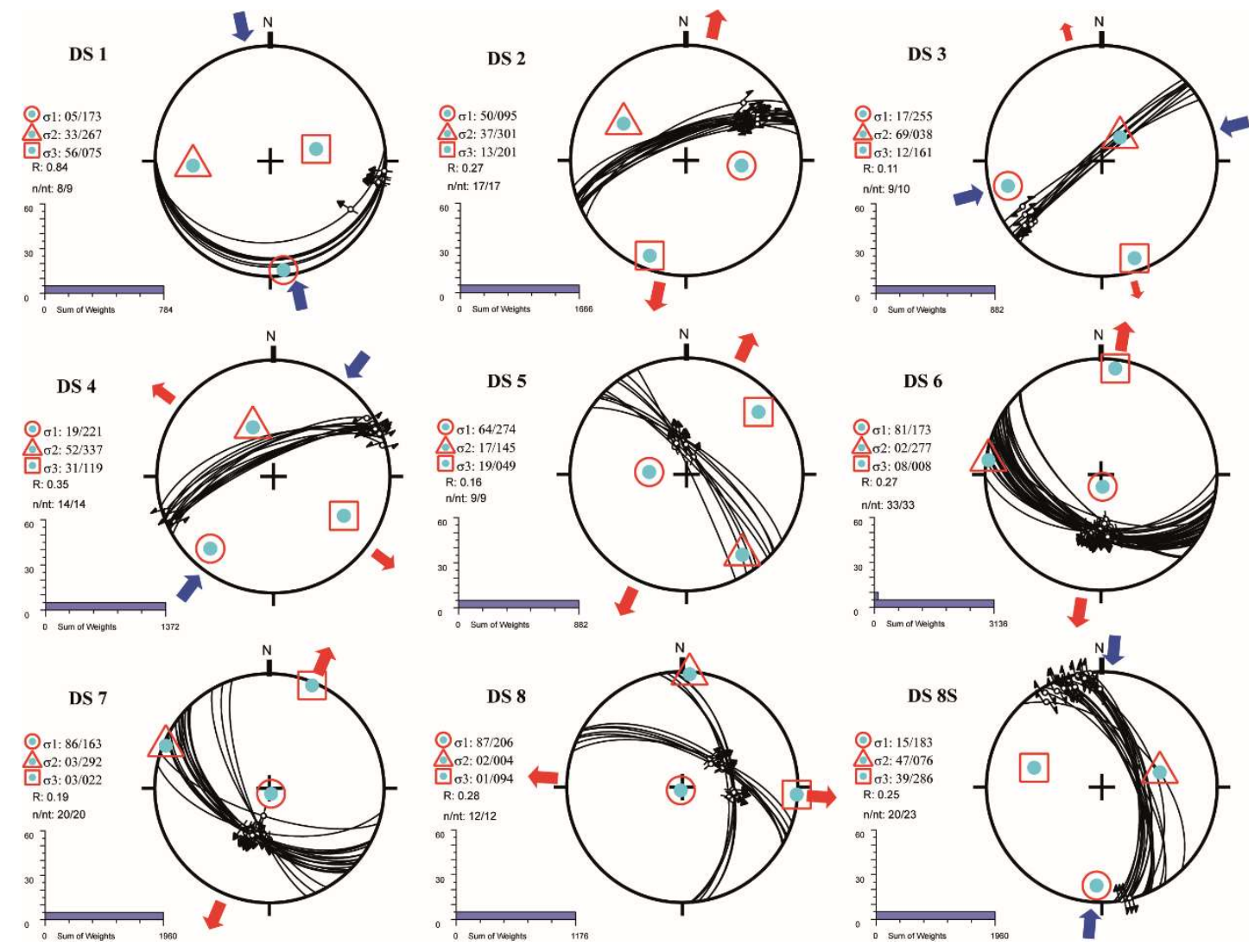
